\title{
Avrupa Konseyi Yerel ve Bölgesel Yönetimler Kongresi Kararlarında Türkiye’de Yerel Demokrasi: Sorunlar ve Çözüm Önerileri
}

\author{
Local Democracy in Turkey in the Decisions of the Congress of Local \\ and Regional Authorities of the Council of Europe: Challenges and \\ Suggestions
}

Mehmet İlker HAKTANKAÇMAZ*

\section{Öz}

Türkiye’nin kurucu üyelerinden olduğu Avrupa Konseyi için, Avrupa'da barış ve istikrarın yapıtaşlarından birini oluşturacağı anlayışıyla, üye ülkelerde yerel ve bölgesel demokrasinin güçlendirilmesi temel hedeflerden biridir. Konsey'in danışma organı olan Avrupa Konseyi Yerel ve Bölgesel Yönetimler Kongresi bu amaçla çalışmalar yürütmekte olup hazırladığı referans belgelerden en önemlisi Avrupa Yerel Yönetimler Özerklik Şartı’dır. Bu çerçevede Kongre, Özerklik Şartı’nın üye ülkelerdeki uygulanma durumunu değerlendirmek üzere olağan ülke izlemeleri gerçekleştirmekte, Şart'ın uygulanması bakımından kaygı verici acil bir durumun ortaya çıkması halinde ise "gerçeğiaraştırma görevi” de düzenleyebilmektedir. Bu faaliyetler neticesinde Kongre, üye ülkelerde yerel demokrasinin uygulanmasına ilişkin değerlendirme ve tavsiyelerde bulunmaktadır. Bu yönüyle Kongre anılan alanda faaliyet gösteren diğer uluslararası kuruluşlardan farklılaşmaktadır. Bu değerlendirme ve tavsiyeler doğrultusunda üye ülkelerde bugüne kadar yerel ve bölgesel yönetimlere ilişkin reform niteliğinde çok sayıda yasal düzenleme hayata geçirilmiştir. Türkiye de Özerklik Şartı’na taraf olduğu tarihten bu yana çok sayıda izleme faaliyetine konu olmuş, Türkiye hakkında hazırlanan tavsiye kararlarının ana konusunu Doğu ve Güneydoğu'da yerel yönetimlerin seçimle gelen organlarının merkezi yönetim tarafından görevden uzaklaştırılması oluşturmuş, bu ise 2010'dan itibaren KongreTürkiye ilişkilerinde tansiyonun yükselmesine yol açmıştır. Bu çerçevede bu çalışmanın amacı; kayyum atama tartışmalarının yoğunlaştığı bir dönemde, Türkiye’ye yönelik izleme faaliyetlerini ve kabul edilen metinleri diğer üye ülkelere yönelik olanlarla karşılaştırmalı şekilde analiz ederek Kongre’nin Türkiye’de yerel demokrasiye bakışını ortaya koymaktır.

Anahtar Kelimeler: Özerklik, Yerel Yönetimler, Demokrasi, Avrupa, Vesayet.

\section{Abstract}

Strengthening local and regional democracy in member states is among the aims of the Council of Europe, whose one of the founding member is Turkey, as it is seen one of the main component of

* İçişleri Bakanlığı, Ankara, E-posta: ilker63@gmail.com, Orcid: 0000-0001-9808-422X 
peace and stability in Europe. The Congress of Local and Regional Authorities, one of the advisory bodies of the Council, conducts various works to realize this aim. The European Charter of Local SelfGovernment is one of the most important reference texts prepared by the Congress. In this frame, the Congress conducts regular general country-by-country monitoring exercises to evaluate the application of the Charter or can carry out urgent fact-finding missions to look into cases of concern and makes evaluations and suggestions on the state of local and regional democracy, which makes the Congress unique among the similar institutions working in this field. Numerous legislative reforms have been set in motion by member states on the basis of the findings of these monitoring activities. Turkey has been subject to many monitoring activities since she was party of the Charter and the main concern in the Congress recommendations about Turkey has been the removal of local elected representatives by the central government in East and Southeast of Turkey. This core issue caused to increase tension in the relations between the Congress and Turkey starting from the year 2010. In this context, the aim of this study is, in such a period when the argument about appointment of caretaker (kayyum) intensified, to reveal the perception of the Congress on the local democracy in Turkey, by scrutinizing the monitoring activities and adopted texts of the Congress on Turkey comparatively with that of the ones on other member states.

Keywords: Self-government, Local Governments, Democracy, Europe, Tutelage.

\section{Giriş}

Avrupa Konseyi (Council of Europe) 5 Mayıs 1949'da 10 Batı Avrupa ülkesinin (İngiltere, Fransa, Belçika, Hollanda, Lüksemburg, İsveç, Norveç, Danimarka, İtalya ve İrlanda) katılımıyla kurulmuştur. Konsey'in, kuruluşundan sadece iki gün sonra İzlanda ve Yunanistan ile birlikte Türkiye’yi kurucu üye olarak üyeliğe davet etmesi üzerine Türkiye Konsey’e, üç ay sonra, 8 Ağustos 1949'da kurucu üye sifatıyla üye olmuştur. Avrupa'da demokrasi, liberalizm ve insan haklarını esas alan ortak bir siyasi değerler bloğu oluşturmak hedefiyle kurulan Konsey 1989 yılına kadar 21 üyeye sahipti. Soğuk Savaş’ın sona ermesi ile standartlarını esneterek eski Doğu Bloku ülkelerini, Avrupa ortak değerlerini bu ülkelerde de egemen kılmak amacıyla üyeliğe kabul etmesiyle Konsey'in bugünkü üye sayısı 47’ye ulaşmıştır (Haktankaçmaz, 2012, s.39; Öncü ve Cevizliler, 2013, s.22-24).

Avrupa Konseyi’nin temel organları; karar organı olan ve üye ülke dışişleri bakanlarından oluşan Bakanlar Komitesi (Committe of Ministers), danışma organı olan ve üye ülkelerin ulusal meclislerinden nüfuslarına göre belirlenen sayıda üye ile temsil edildikleri Parlamenter Meclisi (Parlamentary Assembly) ve yerel demokrasinin geliştirilmesini amaçlayan Yerel ve Bölgesel Yönetimler Kongresi (Congress of Local and Regional Authorities)'dir. İnsan haklarının korunması konusunda uzmanlaşmış kurumlar olan; Avrupa İnsan Hakları Mahkemesi (European Court of Human Rights/AİHM), İnsan Hakları Komiserliği (Commissioner for Human Rights), kısa adıyla İşkenceyi Önleme Komitesi (European Committee for the Prevention of Torture and Inhuman or Degrading Treatment or Punishment) ve yaygın kullanılan adıyla Venedik Komisyonu (The European Commission for Democracy through Law-Venice Commission) ise Konsey’in diğer önemli bileşenleridir. 
Avrupa Konseyỉnin danışma organlarından biri olarak Yerel ve Bölgesel Yönetimler Kongresi (Kongre) üye ülkelerde yerel ve bölgesel demokrasinin geliştirilmesi amacılla bugüne kadar referans belge niteliğinde çok sayıda uluslararası sözleşmenin hazırlanmasına öncülük etmiştir. Bunlar arasında en önemlisi Avrupa Yerel Yönetimler Özerklik Şartı (European Charter of Local Self-Government-ETS 122)'dır. Aynı zamanda Şart’n üye ülkelerde uygulanmasını da izleyen ve bu yönüyle bu alandaki diğer uluslararası kuruluşlardan farklılaşan Kongre, yerel ve bölgesel demokrasinin durumuna ilişkin gözlemleri çerçevesindeki eleştiri ve önerilerini ilgili ülke için hazırladığı rapor ve aldığı tavsiye kararlarına yansitmaktadır (Council of Europe, 1985; Haktankaçmaz, 2012, s.39, 48).

$\mathrm{Bu}$ çerçevede bu çalışmanın amacı; belediyelere kayyum ${ }^{1}$ atamalarının yoğunlaşması nedeniyle yerel yönetimlerin özerkliği tartışmalarının alevlendiği bir dönemde Türkiye’ye yönelik izleme faaliyetleri kapsamında hazırlanan rapor, tavsiye kararı ve diğer metinleri diğer üye ülkelere yönelik olanlarla karşılaştırmalı şekilde inceleyerek Kongre’nin Türkiye’de yerel demokrasiye bakışını ortaya koymaktır.

Çalışma giriş dışında üç bölümden oluşmaktadır. Çalışma kapsamında, ilk olarak Kongre’nin yapısı ve yerel ve bölgesel demokrasinin güçlendirilmesi amacıyla yaptığı çalışmalar hakkında genel bilgiler verildikten sonra, kullanılacak terminolojinin açıklı̆̆ kavuşturulması amacıyla özerklik kavramı yerel ve bölgesel demokrasi bağlamında tartışılacaktır. İzleyen bölümde, Kongre'nin kuruluşundan bu yana Türkiye’ye ilişkin olarak kabul ettiği metinler tek tek incelenerek getirmiş olduğu eleştiri ve öneriler ortaya konulacaktır. Çalışmanın son bölümünde ise, Kongre’nin Türkiye'de yerel demokrasinin geliştirilmesi konusuna yaklaşımı ve Türkiye ile ilişkilerindeki sorun alanları Kongre'nin diğer ülkelere yönelik çalışmalarıyla karşılaştırmalı olarak irdelenecektir. Sonuç bölümünde, genel bir değerlendirmeyle çalışma tamamlanacaktır.

\section{Avrupa Konseyi Yerel ve Bölgesel Yönetimler Kongresi}

Avrupa Konseyi Parlamenterler Meclisi bünyesinde faaliyet gösteren Beledi ve Bölgesel İşler Özel Komitesi (Special Committee on Municipal and Regional Affairs) yerine Ocak 1957'de "istişari" nitelikli olmak üzere oluşturulan Avrupa Yerel Yönetimler Konferansı (Conference of Local Authorities of Europe) kongre yapılanmasına giden sürecin başlangıcıdır. Konferans, Bakanlar Komitesi'nin onayıyla 1961'den itibaren "daimi" statü kazanmış ve 1974'e kadar iki yılda bir toplanmıştır. 1975’te tüzüğünde yapılan değişiklikle sorumluluk alanı bölgeleri de kapsayacak şekilde genişletilerek adı Avrupa Yerel ve Bölgesel Yönetimler Daimi Konferansı (Standing Conference of Local and Regional Authorities of Europe-CLRAE) olarak değiştirilmiş ve her yl toplanmaya başlamıştır (Council of Europe, 2020). Bakanlar Komitesi’nin 1994'te aldığı kararla (Committee of Ministers, 1994) Daimi Konferans, Kongre’ye dönüşmüştür.

Kongre’nin, Yerel Yönetimler Meclisi (Chamber of Local Authorities) ve Bölgeler Meclisi (Chamber of Regions) olmak üzere iki kanadı bulunmaktadır. Üye devletler nüfuslarına göre belirlenen

1 “Kayyum” kavramının doğru kullanımı hakkındaki tartışma için bkz. (Keleş ve Özgül 2017, s.301). 
sayıda üyeden oluşan ulusal heyetleriyle (national delegation) Kongre'de temsil edilmektedir. Ulusal heyet üyeleri kendi ülkelerindeki yerel veya bölgesel bir yönetimde ya halk tarafından seçilerek belli bir göreve getirilmişlerdir ya da halk tarafından seçilmiş bir meclise karşı siyasi sorumluluğa sahiptirler. Parlamenter Meclis'in oluşumuna benzer şekilde, üye devletlerden gelen 324'ü asıl 324'ü yedek üye Kongre’nin iki meclisi arasında dağılmaktadır. Üyeler Kongre bünyesindeki dört farklı siyasi gruptan ${ }^{2}$ kendi siyasi görüşlerine en yakın gördükleri birine de kaydolmaktadır. Kongre teamüllerine göre üyelerin mensubu oldukları ulusal heyetten ziyade içinde yer aldıkları siyasi grubun Kongre’de görüşülecek konulara ilişkin olarak belirlediği tutum çerçevesinde hareket etmeleri beklenir. Bu bakımdan Kongre tarafından Şart'ın uygulanma durumu konusunda gerçekleştirilen denetim yargısal ya da yargi-yargısal değil; siyasidir. İlkbahar ve sonbaharda olmak üzere yılda iki genel oturum için Strazburg'da toplanan Kongre belirli konularda müzakerelerde bulunmakta, taslak raporları incelemekte ve kararlar almaktadır (Council of Europe, 2015, s.6-8; Haktankaçmaz, 2012, s.39-44; Yılmaz, 2018, s.1).

Kongre kararları; bazen "tavsiye" bazen de "tavsiye kararı" şeklinde ifade edilen "recommendation" veya Türkçe'deki "karar" ifadesine karşıllk gelen "resolution" şeklinde olabilmektedir. Tavsiye veya tavsiye kararı; Kongre tarafindan kabul edilen ve Bakanlar Komitesine, Parlamenter Meclisine, Avrupåda veya uluslararası alanda faaliyet gösteren kurum ve kuruluşlara hitaben öneriler içeren metinlerdir. Karar ise; yine Kongre tarafından kabul edilen ancak Kongre'nin kendisine veya üye devletlerden birindeki yerel ve bölgesel yönetimlere hitap eden metinlerdir. Kongre bunların dışında, görev alanında olmak kaydıyla herhangi bir konuda Kongre’nin tutumunu ortaya koyan bildiri (declaration) de yayınlayabilmektedir. Bildiri, toplantı halinde olmadığı zamanlarda Kongre adına işlerin yürütülmesinden sorumlu olan Kongre Bürosu tarafından da yayınlanabilmektedir (Council of Europe, 2018, s.10, 44).

Kongre’nin hazırladığı Avrupa Yerel Yönetimler Özerklik Şartı’na temel oluşturan ilk metin Avrupa Yerel Yönetimler Daimi Konferansı tarafından hazırlanarak 1967'de Avrupa kamuoyuna sunulan Yerel Özerklik İlkeleri Bildirgesi’dir. Daimi Konferans, 1981 yılında da genel nitelikte ve bağlayıcı olmayan bir İlkeler Bildirgesi’ni benimsemiş, bu doğrultudaki çabalar, 1982 yılında Bakanlar Komitesi’ne Avrupa ülkeleri arasındaki yönetsel yapı farklılıklarını dikkate alarak daha esnek kurallar içeren bir Şart Taslağı̀nın sunulmasıyla sonuçlanmıştır. Sonrasında daha da geliştirilen metin Bakanlar Komitesi’nin Haziran 1985'deki toplantısında benimsenerek 15 Ekim 1985'de imzaya açılmıştır. Yürürlüğe girebilmesi için asgari 4 üye ülke tarafından onaylanması koşulu bulunan Şart, 1 Eylül 1988 tarihinde bu onay sayısına ulaşılmasıyla resmen yürürlüğe girmiştir. Şart, hali hazırda Konsey üyesi 47 ülkenin tamamı tarafından onaylanmıştır (Keleş, 1995, s.3-4; Köşger ve Haktankaçmaz, 2011, s.51).

2 Kongre bünyesindeki siyasi gruplar şunlardır: Avrupa Halk Partisi-Hıristiyan Demokratlar Grubu (EPP/CD-Group European People's Party-Christian Democrats); Sosyalistler, Yeşiller ve İlerici Demokratlar Grubu (SOC/G/PDGroup of Socialists, Greens and Progressive Democrats); Avrupa Muhafazakârlar ve Reformcular Grubu (ECR-The European Conservatives and Reformists Group); Bağımsız ve Liberal Demokratlar Grubu (ILDG-Independent and Liberal Democrat Group). Genel kural olmamakla birlikte, Türkiye Ulusal Heyeti üyelerinden AK Parti mensupları EPP/CD'ye, CHP ve BDP mensupları SOC/G/PD'ye, MHP mensupları ECR'ye ve İII Parti mensupları ILDG'ye katılmaktadır (Council of Europe, 2020b). 
Kongre, kuruluşundan bu yana, üye devletlerde yerel ve bölgesel demokrasinin güçlendirilmesi hedefini gerçekleştirmek amacıyla çok çeşitli mekanizma ve programları uygulamaya koymuştur. Bunlar içinde en önemlisi ve simgesel olanı Şart’nn üye ülkelerdeki uygulanışının düzenli aralıklarla değerlendirilmesine imkân sağlayan izleme görevi (monitoring mission)'dir.

Kongre’nin üç komitesinden biri olan İzleme Komitesi (Monitoring Committee) bu amaçla üye ülkelere ilke olarak beş yılda bir izleme görevinin gerçekleştirilmesini koordine etmektedir. Her bir ulusal heyetten kimlerin Komitede görev yapacağı ulusal heyetlerin başkanları tarafından belirlenmektedir. İzleme Komitesi’nin, tarafsızlığı sağlamak üzere belirlenmiş kriterler göz önünde bulundurularak, her bir izleme görevi için kendi üyelerinin de katılımıyla oluşturduğu izleme heyetleri ülke ziyaretleri gerçekleştirmekte ve ulaştığı sonuçlara ilişkin bir rapor hazırlamaktadır. Hazırlanan rapor Kongre’nin izlenen ülkeye ilişkin olarak alacağı tavsiye kararına esas teşkil etmektedir. Kural olarak, izlenecek ülkeye bir ziyaret gerçekleştirilmektedir ancak heyetin gerek görmesi ve Komite’nin onayılya izlenecek ülkeye ikinci bir ziyaret daha yapılabilmektedir. İzleme Komitesi ayrıca üye ülkelerde yerel ve bölgesel demokrasinin işleyişiyle ilgili kaygı yaratacak bir uygulamanın varlı̆̆ halinde her zaman "gerçeği-araştırma görevi (fact-finding mission)" düzenlenmesi için heyet oluşturabilmektedir.

İzleme süreci ilgili ülke makamlarıyla işbirliği halinde yürütülmektedir. İzleme heyeti, ziyaret kapsamında yerel ve bölgesel yönetimlerden sorumlu bakan, milletvekilleri, yerel ve bölgesel seçilmişler, sivil toplum örgütü ve medya temsilcileri başta olmak üzere o ülkede yerel ve bölgesel demokrasinin durumu hakkında bilgi verebilecek tüm taraflarla görüşmeler gerçekleştirmektedir (Council of Europe, 2018, s.60, 87-92; Haktankaçmaz, 2012, s.48-49).

\section{Kavramsal Çerçeve: Yerel ve Bölgesel Yönetimlerin Özerkliği}

Yerel ve bölgesel demokrasi bağlamında özerkliğin Kongre tarafından bugüne kadar hazırlanan referans belgeler ışığında çerçevesinin ortaya konulması hem bu makalede kullanılacak terminolojinin açıklığa kavuşturulması hem de Kongre’nin ülkemize yönelik çalışmalarının kapsamının anlaşılması bakımından gereklidir.

İster yerel ister bölgesel olsun, ulusaltı yönetim birimlerinin sadece kamu hizmeti üretmekle görevli olmadığı (Keleş, 2011, s.10), yerel ve bölgesel demokrasinin varlığının demokratik toplumun temellerinden biri olduğu (Committe of Ministers, 1994) ve demokrasi açığını kapatmak isteyen ülkelerin demokrasiyi yerel ve bölgesel düzeyde de güçlendirmesi gerektiği (Keleş, 2010, s.22), bu yönetimlerin gereği gibi işlev görebilmelerinin özerk olmalarına bağlı olduğu (Keleş, 2011, s.10) ifade edilegelmiştir.

Bir topluluğun yönetimi için gerekli kuralların yine o topluluğu oluşturan bireylerce belirlenmesi anlamını taşıyan özerklik, egemenlik kavramına çok benzemekle birlikte ondan ayrılmaktadır. Egemenlik mutlak, özerklik sınırlı bir kavramdır. Yerindenlik (subsidiarity) ilkesi de yerel ve 
bölgesel yönetimlerin özerkliği ile yakından ilgili olup kamusal sorumlulukların onu en iyi biçimde yapabilecek yönetim basamağına verilmesini ifade etmektedir (Keleş, 2011, s.12-13).

Avrupa Yerel Yönetimler Özerklik Şartı ve onun tamamlayıcısı niteliğinde fakat bağlayıcı olmayan, bölgesel yönetimlerin hak ve sorumluluklarının belirlenmesi amacıyla hazırlanmış olan 2009 tarihli Bölgesel Demokrasi İçin Başvuru Çerçeve Belgesi (Reference Framework for Regional Democracy) (Avrupa Konseyi, 2017) yerel ve bölgesel yönetimlerin özerkliği kavramlarının açıklanmasında esas alınması gereken iki temel belgedir.

Yerel yönetimler, belli bir toprak üzerinde yaşayan insan topluluğunun oluşturduğu ve merkezi yönetim (devlet) karşısında sınırları yasalarla belirlenmiş bir özerkliğe sahip ama onun vesayetine tâbi olan kamu tüzel kişileridir (Gözler, 2019, s.2). Şart’a göre yerel özerklik; yerel yönetimlerin yasalar çerçevesinde, kamu hizmetlerinin önemli bir bölümünü kendi sorumlulukları altında ve yerel halkın çıkarları doğrultusunda düzenleme ve yönetme hakkını ifade eder. Yerel yönetimler bu haklarını, doğrudan, eşit, gizli ve genel oy ilkesine dayalı olarak serbestçe seçilmiş üyelerden oluşan meclisler eliyle kullanırlar (Yeter, 1996, s.4; Özerklik Şartı, md.3). Şart’ın 4'üncü maddesinde özerk yerel yönetimin kapsamı ortaya konulmuş; temel yetki ve sorumlulukların anayasa veya yasalarla belirlenmesi, yasalarla yetki alanı dışında bırakılmış olmayan ve başka yönetimlere de verilmemiş her konuda faaliyet gösterilebilmesi (genel yetki ilkesi), kamusal hizmetlerin yerindenlik ilkesine göre görülmesi, yetkilerin tam ve münhasır olması ve yasalarla öngörülen durumlar dışında sinırlandırılamaması, üst yönetimler tarafından yerel yönetimlere yetki devredilmesi durumunda bu yetkilerin yerel koşullara uydurularak kullanabilmesi ve son olarak, ülkemizin çekince ${ }^{3}$ koyduğu, kendilerini doğrudan ilgilendiren konularda yerel yönetimlere danışılması şeklinde ilkeler sıralanmıştır. Şart’ta, bunların yanı sıra yerel özerkliğe ilişkin olarak yerel yönetimlere sağlanacak mali güvenceler, merkezi yönetimin denetim ve gözetiminin çerçevesi, yerel yönetimler arası işbirliği, yerel yönetimlerin sınılarının korunması ve yargı yoluna başvurabilme güvencesi başlıkları altında gruplandırılabilecek diğer hususlara yer verilmiştir.

Buradan hareketle, yerel yönetimlerin özerkliği için üç temel şarttan söz edilmektedir. Bunlardan ilki yerel yönetimlerin yasalarla belirlenen sinırlar içinde merkezin müdahalesi olmadan kesin karar alabilme hakk1, ikincisi; karar organlarının seçimle işbaşına gelmesi ve son olarak; yerel yönetimlerin sorumluluklarını yerine getirebilmek için yeterli mali kaynaklara sahip olabilmesidir (Sertesen, 2011, s.2-3).

3 Kamuoyunda ve akademik yazında “Türkiye’nin Özerklik Şartı’na çekince koyduğu” şeklindeki ifade sıkça kullanılmakta ise de bu hukuken doğru bir kullanım değildir. Çünkü Şart’nn 12'nci maddesinin 1'inci fikrasında "Her Âkit Taraf, bu Şart’n I. bölümündeki fikralardan en az 10 tanesi aşağıdakilerin arasından seçilmek üzere en az 20 fikrası ile kendisini bağlı saymayı taahhüt edecektir." hükmü yer almaktadır. Bu fikra hükmüne uygun olarak Türkiye tarafından Şart'ın birinci bölümündeki fikralardan 20 tanesi seçilerek kabul edilmiş olup Şart'ın diğer hükümlerine ayrıca bir çekince konulmamıştır. Kaldı ki, Şart'ta ortaya konulan yöntem bakımından ne Türkiyennin ne de bir başka ülkenin Şart’’n herhangi bir hükmüne çekince koyması teknik olarak zaten mümkün değildir. Ancak hem kullanım kolaylığı hem de galat-ı meşhur lügat-i fasihten evladır deyiminden hareketle bu nüans göz ardı edilerek çalışmada çekince ifadesi kullanılmıştır. 
Şart, birbirinden çok farklı yerel yönetim yapılanmalarına sahip olan Konsey üyesi ülkelerde bu farklılıkları giderme amacı taşımadığı gibi (Yeter, 1996, s.5) yerel yönetimlerin "devlet içinde devlet" olmalarını öngören bir belge de değildir. Şart’a göre yerel yönetimler sınırları yasalarla belirlenmiş bir özerklikten yararlanan, ama kesinlikle "bağımsız" olmayan yönetim birimleridir (Erbay ve Keleş, 2013, s.26). Bir yandan kamu hizmeti üretmek ve sunmakla görevli olmaları diğer yandan halkın kendini yönetebilmesine imkân vermeleri, yerel yönetimlere "siyasal" bir kimlik kazandırmaktadır. Siyasal kimlik sahibi olmaları, bu yönetimlerin "siyasal yerinden yönetim (siyasi adem-i merkeziyet)" kuruluşları olduğu anlamına gelmemektedir. Yerel yönetimler her ülkede "yönetsel yerinden yönetim (yönetsel adem-i merkeziyet)" kuruluşlarıdır ve kamu hizmetlerinin bir bölümünü üstlenirler. Siyasal süreçlerle oluşturulan organlara sahip olmaları, demokratik ve katılıma dayalı kurumlar olmalarının gereğidir (Keleş, 2011, s.10). Bu çerçevede Türkiye de, siyasal yerinden yönetim ilkesine göre değil, yönetsel yerinden yönetim ilkesine göre kurulmuş üniter bir devlettir. Esasında Özerklik Şartı’nı yerel demokrasinin kalitesinin yükseltilmesini ve ölçülmesini amaçlayan bir göstergeler manzumesi, idari ve mali özerklikten oluşan yerel özerkliği de bu göstergelerin en önemlisi olarak saymak gerekir. Ancak Türkiye kamuoyunda özerkliğin sıkça siyasi özerklik biçiminde algılanması yerel özerkliğin doğru biçimde anlaşılmasına engel olmaktadır (Yontar ve Özer, 2018, s.99, 108-109).

Bölgesel Demokrasi İçin Başvuru Çerçeve Belgesi (Çerçeve Belgesi) ise; bölge yönetimlerinin yapıları, örgütlenmeleri, yetkileri, mali kaynakları, devlet içinde diğer yönetimlerle ve vatandaşlarla ilişkileri konusunda ilkeler içermektedir. Çerçeve Belgesinnde, bölge yönetimleri; seçimle oluşturulmuş bir meclise sahip, yönetsel açıdan hiyerarşik ilişki koşulu olmamakla birlikte merkezi yönetimle yerel yönetimler arasında bir yerde bulunan, kendi örgütlenmesini kendi başına veya merkezi yönetimin kurallarına bağlı olarak yapabilen, yasalarla kendilerine yasaklanmamış veya başka yönetimlere de verilmemiş konularda (genel yetki ilkesi) faaliyette bulunma ve yerindenlik ilkesine uygun olarak bölge halkının çıkarları doğrultusunda hizmet sunma hak ve yetkisine sahip mülki birimler olarak tanımlanmıştır. Ayrıca, idari yapılanmada bölgesel yönetim kademesinin benimsendiği ülkelerde bölgesel özerkliğin (regional selfgovernment) de anayasal veya yasal düzeyde tanınması gerektiği ifade edilmiştir (Avrupa Konseyi, 2017, s.14-26). Ülkemizde bugüne kadar farklı amaçlarla istatistiki bölge (NUTS), coğrafi bölge, kalkınmada öncelikli bölge, plan bölgesi, havza bölgesi gibi bölge tanımları yapılmış (Toksöz ve Gezici, 2014, s.14-21) ve Anayasảnın 126'ncı maddesine göre yol, su, orman başta olmak üzere merkezden yürütülen pek çok hizmet için bölgesel yönetim teşkilatları kurulmuşsa da (Işıkçı, 2018, s.227), Çerçeve Belgesi’ndeki ilkeler 1şı̆ı̆ında değerlendirildiğinde bunların Kongre’nin ilgi alanındaki bölgesel yönetimler olmadığı açıktır. Dolayısıyla, bulunan pratik bir çözümün sonucu olarak, büyükşehir belediye başkan ve meclis üyeleri ile il genel meclisi üyeleri arasından belirlenen temsilcilerin ülkemizi Kongre’nin Bölgeler Meclisi’nde diğer belediye başkan ve meclis üyeleri arasından belirlenenlerin ise Yerel Yönetimler Meclisi'nde temsil etmesi şeklinde bir uygulama varsa da, Kongre’nin ülkemize yönelik çalışmaları bölgesel demokrasinin değil yerel demokrasinin güçlendirilmesi bağlamındadır ve bu çalışmada da bu açıdan ele alınmıştır. 
Çalışmamızın kapsamı dışında bırakılan bölgesel özerklik üzerinde daha fazla durulmayacak olmakla birlikte Kongre’nin özerklik meselesine genel yaklaşımının bir parçası olarak bölgesel özerklikle ilgili bir hususun ifade edilmesinde yarar vardır. "Bölgeselleşme", bölgesel düzeyde kendi yazgısını belirleme hakkına (self-determinasyon) sahip olma isteğini ifade eden "bölgecilik"ten farklı olarak, yönetsel bir sürece ve bir yönetim tekniğine karşılık gelmektedir. Bu anlamda "bölgesel özerklik" de bölge yönetimlerinin kendi ulusal yasaları içindeki kurumsal konumlarına karşlık gelen bir terimdir (Keleş ve Erbay, 1999, s.20). Nitekim Avrupa Birliği içinde beş ayrı bölgeselleşme türünden bahsedilmektedir. Yönetsel bölgeselleşme, var olan yerel yönetimler eliyle bölgeselleşme ve bölgeler çapında yerel yönetim birimleri oluşturmak suretiyle bölgeselleşme şeklindeki türlerde bölgelere yasama erki tanınmamıştır. Siyasal (ya da kurumsal) bölgeselleşme türünde ise bölge yönetimleri yasama erkini kullanabilmektedirler. İspanya ve İtalya'daki bölge yönetimleri ile İngiltere ve Portekiz'in bazı bölgeleri bu şekildedir. Federe devlet birimleri yoluyla bölgeselleşme ise federal devlet sistemlerindeki bölgeselleşmeyi anlatır. İsviçre kantonlarıyla Belçikảnın bölgeleri bu türdedir (Keleş, 2011, s.26). Ülkemizde de ulus devlete sıcak bakmayan bölgecilik savunucuları tarafından ulusal yasalar içinde yürütülen yönetsel süreçleri tanımlayan "bölgeselleşme" ve "bölgesel özerklik" kavramlarının Avrupa Konseyi kurumlarına atıf yapılarak kendi "bölgecilik" hedefleri doğrultusunda ve anlamının dışına taşarak kullanıldığına tanık olunmaktadır (Erbay ve Keleş, 2013, s.30-31). Oysa, Çerçeve Belgesi’nin, "Sadakat, Toprak Bütünlüğü ve Bağlllık” başlıklı bölümündeki 2528 arası maddelerde; bölgesel yönetimlerle merkezi yönetim arasındaki ilişkinin karşılıklı sadakat ilkesine dayanacağı, devletin birliğine, egemenliğine ve toprak bütünlüğüne saygıyı gerektireceği, bu maddelerin açıklamalarının yer aldığı kısmında ise; özerkliğin bağımsızlık anlamına gelmeyeceği, Çerçeve Belgesi’nde sıralanan özerklik ilkelerinin "ayrılıkçı" bir anlamda yorumlanmaması için bölgesel yönetimlerin devlete karşı yükümlülükleri arasında devletin birliği, egemenliği ve toprak bütünlügüne saygı ilkelerinin yer aldığı çok açık biçimde ifade edilmiştir (Avrupa Konseyi, 2017, s.38-39).

\section{Kongre’nin Türkiye’de Yerel Demokrasiyi İzleme Faaliyetleri}

Kongre, diğer üye ülkelerde olduğu gibi, Türkiye'de de yerel demokrasiyi güçlendirmek amaciyla Özerklik Şartı’nın uygulanma durumuna ilişkin izleme ve gerçeği-araştırma faaliyetleri yürütmüştür.

Tablo-1'den de görüleceği üzere, Kongre tarafından bugüne kadar Türkiye'de yerel demokrasinin durumu hakkında, birisi tamamlanma aşamasında, toplam yedi izleme görevi gerçekleştirilmiş olup bunların dördü periyodik izleme, üçü ise gerçeği-araştırma görevi şeklindedir. Görevlerin tamamlanmasını takiben Türkiye'de yerel demokrasinin durumuna ilişkin olarak kabul edilen tavsiye kararlarının yanı sıra farklı zamanlarda alınan diğer kararlar ve bildiriler de bulunmaktadır. 
Tablo 1: Kongre’nin Türkiye’de Yerel Demokrasiyi İzleme Faaliyetleri Kapsamında Aldığı Kararlar

\begin{tabular}{|c|c|c|c|c|c|}
\hline \multirow{2}{*}{$\begin{array}{l}\text { S. } \\
\text { No }\end{array}$} & \multirow[t]{2}{*}{ Tavsiye } & \multicolumn{3}{|c|}{ Görev Kapsamındaki Ziyaret Tarihleri } & \multirow[t]{2}{*}{ Görevin Konusu } \\
\hline & & 1.ziyaret & 2.ziyaret & 3.ziyaret & \\
\hline 1 & $29(1997)$ & $\begin{array}{l}\text { 4-8 Aralık } \\
1996\end{array}$ & - & - & $\begin{array}{l}\text { Doğu ve Güneydoğu'da görevden alınan } \\
\text { belediye başkanları ve boşaltılan köyler } \\
\text { nedeniyle ilk periyodik izleme }\end{array}$ \\
\hline 2 & 176(2005) & 3-7 Ekim 2001 & 22-24 Kasim 2004 & 21-23 Mart 2005 & $\begin{array}{l}\text { Periyodik izleme ve bilahare Doğu ve } \\
\text { Güneydoğu'da dört belediye başkanının } \\
\text { görevden uzaklaştırılmasını inceleme }\end{array}$ \\
\hline 3 & $229(2007)$ & $\begin{array}{l}\text { 8-10 Ağustos } \\
2007\end{array}$ & - & - & $\begin{array}{l}\text { Sur belediye başkanının görevden } \\
\text { uzaklaştırılması (Gerçeği-araştırma } \\
\text { görevi) }\end{array}$ \\
\hline 4 & $301(2011)$ & $\begin{array}{l}25-27 \text { Şubat } \\
2008\end{array}$ & 12-14 Ocak 2009 & $\begin{array}{l}\text { 10-11 Mayıs } \\
2010\end{array}$ & Periyodik izleme \\
\hline \multirow[b]{2}{*}{5} & $355(2014)$ & 6 Ekim 2011 & 7 Aralık 2013 & - & \multirow[b]{2}{*}{$\begin{array}{l}\text { Kongre üyesi bir belediye başkanı ile } \\
\text { birlikte Doğu ve Güneydoğu’da yerel } \\
\text { seçilmişlerin terör örgütü üyeliğinden } \\
\text { tutuklanması (Kongre Bürosu kararılyla } \\
\text { özel görev) }\end{array}$} \\
\hline & \multicolumn{4}{|c|}{$\begin{array}{l}\text { Ayrıca aynı konuda; } \\
\text { Bildiri (Kongre Bürosu)2010 } \\
\text { Bildiri (Declaration 1(2013) } \\
\text { Karar (Resolution 367(2014) } \\
\end{array}$} & \\
\hline \multirow[b]{2}{*}{6} & $397(2017)$ & 3-4 Ekim 2016 & $\begin{array}{l}\text { 18-20 Aralık } \\
2016\end{array}$ & - & \multirow{2}{*}{$\begin{array}{l}\text { Doğu ve Güneydoğu'da yerel seçilmişlerin } \\
\text { terör örgütü üyeliğinden tutuklanarak } \\
\text { görevden uzaklaştırıl-ması ve yerlerine } \\
\text { kayyum atanması (Gerçeği-araştırma } \\
\text { görevi) }\end{array}$} \\
\hline & \multicolumn{4}{|c|}{$\begin{array}{l}\text { Ayrıca aynı konuda; } \\
\text { Karar (Resolution 416(2017) }\end{array}$} & \\
\hline 7 & - & 1-3 Ekim 2019 & $\begin{array}{l}\text { 12-13 Kasım } \\
2019\end{array}$ & - & Periyodik izleme \\
\hline
\end{tabular}

Kaynak: Tabloda yer alan bilgiler Avrupa Konseyỉnin internet sayfası www.coe.int adresinden derlenmiş olup erişim bilgisi her bir karar ve bildirinin metin içinde detaylı incelenmesi sırasında verilmiştir.

\subsection{9(1997) sayılı Tavsiye (Recommendation 29(1997)}

Tavsiye (Congress, 1997a) Kararı, Türkiye’ye yönelik 4-8 Aralık 1996 tarihlerini kapsayan ilk izleme ziyaretini takiben alınmıştır. Her ne kadar izleme süreci Doğu ${ }^{4}$ ve Güneydoğu'da görevden uzaklaştırılan belediye başkanları ve meclis üyeleri ile boşaltılan köylere ilişkin olarak Kongre’ye iletilen şikâyetler üzerine başlatılmışsa da gerek Tavsiye Kararı gerekse dayanağı İzleme Raporu (Congress, 1997b) daha çok Türkiye’de yerel demokrasiyle ilgili genel konulara odaklanmıştır.

İzleme Raporu’nda Türkiye'de olası bir yerel yönetimler reformunu zorlaştırabilecek iki temel sorun çok isabetli bir şekilde ortaya konulmuştur. Rapor’a göre bunlardan birincisi; Osmanlı döneminden ve Cumhuriyet'in ilk yıllarından gelen yönetsel gelenekler ve yerel yönetim mevzuatıdır. $\mathrm{Bu}$

4 Kongre bünyesinde Türkiye'ye ilişkin olarak hazırlanan metinlerde south eastern part of the country, South-East of the country, south eastern Turkey, south-east of Turkey, south-east Turkey, South-Eastern Anatolia gibi faklı tanımlamalar kullanılmışsa da biz tüm bu tanımları görevden uzaklaştırılan yerel seçilmişlerin görev yaptıkları coğrafi bölgenin doğru bir şekilde belirtilebilmesi bakımından "Doğu” ifadesini ekleyerek Türkçe’ye çevirmeyi yeğledik. 
kapsamda, yüksek düzeyde merkeziyetçiliğe dayanan üniter devlet geleneğinin modern Türk devletinde ihtiyaç duyulan reformların gerçekleştirilmesinin önünde ciddi engel oluşturabileceği özellikle vurgulanmıştır (Para 9/i). Rapora göre ikinci temel sorun ise; yaşanan bir dizi hükümet kriziyle ortaya çıktı̆̆ı üzere Türk siyasal yapısındaki zayıflıktır (Para 9/ii). Bu ikincisiyle; 2000’li yıllara kadar sıkça yaşanan koalisyonlar nedeniyle kurulan hükümetlerin reform yapacak güce sahip olmayışına ve siyaset üzerindeki askeri bürokrasi kaynaklı vesayete atıf yapılmaktadır.

29(1997) sayılı Tavsiye'de ve dayanağı Rapor'da en fazla eleştirilen iki konu merkezi yönetimin yerel yönetimler üzerinde sahip oluğu vesayet yetkileri ve bu kapsamda yerel yönetimlerin seçilmiş organlarının görevden uzaklaştırılması uygulamasıdır.

Tavsiye'de yer alan Türk yerel yönetim sistemine yönelik başlica eleştiri ve öneriler şu şekilde özetlenebilir:

- Anayasảnın 127’nci maddesindeki merkezi yönetimin yerel yönetimler üzerindeki vesayet yetkisi sona erdirilmelidir.

- İçişleri Bakanı́nın yerel yönetimlerin seçimle gelen organlarını veya organlarının üyelerini görevden uzaklaştırabilmesine ilişkin yetki yargıya devredilmelidir.

- Yerel meclislerin siyasi konuları görüşmesini yasaklayan kural kaldırılmalıdır.

- Yerel yönetimlere sağlanan mali kaynaklar arttırılmalı ve onlara vergileme dahil kendileri için yeni gelir kaynağı yaratabilme yetkisi tanınmalıdır.

- İl özel idarelerinin yapısı, valinin konumunu da içerecek şekilde gözden geçirilmelidir.

- Köyler yetkileri arttırılacak şekilde yeniden yapılandırılmalıdır.

- Atanmışüye sayısının seçilmişüyelerden fazla olduğu encümenleryeniden yapılandırılmalıdır.

- Yerel yönetimlere STK'lar ve vatandaş meclisleriyle birlikte çalışabilme ve onların faaliyetlerini finanse edebilme yetkisi verilmelidir.

- Yerel yönetimlerin serbestçe kendi aralarında birlik kurabilmeleri ve sınır ötesi işbirliği yapabilmeleri yasal güvence altına alınmalıdır.

- Yerel yönetim meclislerinin karar alma süreçlerindeki etkinlikleri arttırılmalı, meclis üyelerine bağımsız çalışabilmelerini sağlayacak güvenceler sağlanmalıdır.

- Yerel yönetim personel sistemi, personelin belediye veya il genel meclisleri kararıyla işe alınmalarını ve bu meclislerin sorumluluğu altında çalışmalarını sağlayacak şekilde yeniden yapılandırılmalıdır.

- Mümkünse Türk Belediyecilik Derneği (o zamanki adıyla) bünyesinde yerel yönetimlerle ilgili bir "eğitim ve araştırma merkezi" kurulmalıdır.

- Avrupa Yerel Topluluklar veya Yönetimler Arasında Sınır Ötesi İşbirliği Çerçeve Sözleşmesi ${ }^{5}$ ve EkiProtokole (theEuropean Outline Convention on TransfrontierCo-operation between Territorial

5 Bu Sözleşme (eki Protokol değil) Türkiye tarafından 04.02.1998 tarihinde imzalanmış ve Bakanlar Kurulu’nun 
Communities or Authorities-ETS 106 and its additional Protocol-ETS 159), Yabanciların Yerel Düzeyde Kamu Hayatına Katılması Hakkında Avrupa Sözleşmesine (European Convention on the Participation of Foreigners in Public Life at Local Level-ETS 144), Bölgesel veya Azınlık Dillerinin Korunması Hakkında Avrupa Sözleşmesine (the European Charter for Regional or Minority Languages-ETS 148) ve Ulusal Azınlıkların Korunması Hakkında Avrupa Çerçeve Sözleşmesine (the European Framework Convention on the Protection of National MinoritiesETS 157) Türkiye’nin taraf olması hususu değerlendirilmelidir.

\subsection{6(2005) sayılı Tavsiye (Recommendation 176(2005)}

Kongre, bir önceki tavsiye kararının uygulanma durumunu değerlendirmek üzere periyodik izleme kapsamında yeni bir izleme süreci başlatmıştır. Süreç, her ne kadar periyodik izleme kapsamında başlatılmışsa da bilahare raportörlerden, Doğu ve Güneydoğu Anadolu'daki dört belediye başkanının görevden uzaklaştırılması konusunda Kongre’ye ulaşan şikâyetleri de incelemeleri istenmiştir.

Söz konusu Tavsiye (Congress, 2005a), iki izleme raporu esas alınarak hazırlanmıştır. İlk Rapor (Congress, 2001) 3-7 Ekim 2001 tarihlerini kapsayan izleme ziyaretinin ardından hazırlanmış olup iki ana bölümden oluşmaktadır. Raporun birinci bölümünde Türkiye’de yerel demokrasiyle ilgili genel konulara değinilmişken ikinci bölüm yerel seçilmişlerin, özellikle de dört belediye başkanının (Şemdinli, Özalp, Lice ve Ağrı) görevden uzaklaştırılması konusuna ayrılmıştır

İkinci Rapor (Congress, 2005b) ise, ilk raporu tamamlayıcı mahiyette olup 22-24 Kasım 2004 ve 21-23 Mart 2005 tarihli iki ayrı ziyareti takiben hazırlanmıştır. Rapor'da, Türkiye'de yerel yönetimlerle ilgili genel hususlar ele alınmış, o dönem yeni kurulan AK Parti hükümetinin başlattığı yerel yönetimler mevzuatını yenileme çalışmalarına ve yerel seçilmişlerin görevden uzaklaştırılması konularına değinilmiştir.

176(2005) sayılı Tavsiye'de yer alan hususlar şu şekilde özetlenebilir:

- Yerel yönetimlere ilişkin yeni mevzuat memnuniyetle karşılanmıştır fakat bu mevzuatın sağlıklı bir değerlendirmesi ancak uygulama görüldükten sonra yapılabilir. Bununla birlikte, yenilenen mevzuatla yerel yönetimlere geniş yetkiler verilmiş olsa da merkezi yönetimin sahip olduğu vesayet yetkileri nedeniyle Kongre için bu yetkilerin "tam ve münhasır (full and exclusive)" olarak tanımlanması mümkün değildir. Dolayısıyla, iddialı reform programı kapsamında yürürlüğe giren mevzuata rağmen Türk yerel yönetim sisteminde çok az değişiklik meydana gelmiştir.

- Yeni Köy Kanunu’nun, Kamu Hizmetleri Hakkında Kanun’un çıkarılması ve özellikle daha önceki raporlarda sıkça eleştirilen yerel yönetim organlarının görevden uzaklaştırılmasına ilişkin konu başta olmak üzere Anayasa değişikliğinin yapılması hala önemini korumaktadır. 
- Genel olarak gelirler, yerel hizmetlerin etkin yönetimini güvenceye almaktan uzaktır. Yeni bir Belediye Gelirleri Kanunu çıkarılmalı, yerel yönetimlere kendilerinin belirleyeceği yeni vergi ve benzeri mali yükümlülük getirebilme yetkisi tanınmalıdır.

- Yerel yönetimler arası gelişmişlik farklarını azaltacak objektif kriterlere dayalı bir mali denkleştirme sistemi geliştirilmeli, merkezi yönetimden yerel yönetimlere gönderilen tahsisatlar herhangi bir amaca özgülenmemiş olmalıdır.

- Türkiye Belediyeler Birliğí ${ }^{6}$ yerel yönetimlere ilişkin politika yapım sürecinde merkezi yönetimin daimi paydaşı haline gelmelidir.

- Yerel yönetimlerin yüksek vasıflı personel istihdam edebilmesini güvenceye alacak adımlar atılmalıdır.

- Yerel yönetimlerin yurtdışı ilişki kurabilmeleri için önceden İçişleri Bakanlığı̉ndan izin almaları şart kaldırılmalıdır.

\subsection{9(2007) sayılı Tavsiye (Recommendation 229(2007)}

Tavsiye (Congress, 2007) 8-10 Ağustos 2007 tarihlerinde, Sur Belediye Başkanı’nın görevden uzaklaştırılması konusunda düzenlenen gerçeği - araştırma ziyareti sonrası hazırlanmıştır.

Kongre’nin, söz konusu kararında;

- Yerel yönetimlerin kamu hizmetlerinin sunumunda Türkçeden başka dilleri kullanabilmelerine izin verilmesi,

- Belediye Kanunu’nun belediye başkan ve meclis üyelerinin takibata uğrama korkusu olmaksızın siyasi konularda karar alabilmelerine imkân tanıyacak şekilde değiştirilmesi,

- Türkiye’nin, yerel azınlıkların ve yerel dillerin korunmasına ilişkin ilk Tavsiye Kararı’nda belirtilen Avrupa Konseyi sözleşmelerini onaylaması,

- hususları dile getirilmiştir.

\subsection{1(2011) sayılı Tavsiye (Recommendation 301(2011)}

Tavsiye (Congress, 2011a), periyodik izleme kapsamında 25-27 Şubat 2008, 12-14 Ocak 2009 ve 10-11 Mayıs 2010 tarihlerinde gerçekleştirilen üç ziyareti takiben hazırlanan Rapor (Congress, 2011b) esas alınarak hazırlanmıştır.

301(2011) sayılı Tavsiye'de yer alan eleştiri ve öneriler şu şekilde özetlenebilir:

- Anayasảnın 127’nci maddesindeki ve diğer yasalardaki vesayet yetkisi devam ettirilmektedir.

- Mevcut ceza ve terörle mücadele kanunlarının uygulanma şekli Türkiye’de yerel demokrasinin işleyişi ve yerel seçilmişlerin insan hakları üzerinde haddinden fazla yıkıcı etkiye sahiptir.

6 176(2005) sayılı Tavsiye'nin 20/b maddesindeki "the Association of Turkish Municipalities" ifadesi, makalede kavram bütünlügünün sağlanması amacıyla, Türkiye Belediyeler Birliği olarak Türkçe’ye çevrilmiștir. 
- Belediye başkan ve meclis üyelerinin siyasi konularda takibata uğrama korkusu olmaksızın karar alabilmelerine ve yerel yönetimlerin kamu hizmetlerinin sunumunda Türkçeden başka dilleri kullanabilmelerine izin verilmesini içeren 229(2007) sayılı Tavsiye’nin uygulanması için hiçbir adım atılmamıştır.

- Yeni Belediye Gelirleri Kanunu ve İl Özel İdare Gelirleri Kanunu çıkarılmalıdır. 5779 sayılı İl Özel İdarelerine ve Belediyelere Genel Bütçe Vergi Gelirlerinden Pay Verilmesi Hakkında Kanun bu yönetimleri merkezi yönetimden aktarılan kaynaklara çok daha bağımlı hale getirmiştir.

- 5747 sayılı Kanunla (Büyükşehir Belediyesi Sınırları, 2008) pek çok belediyenin köye dönüştüğü de göz önüne alınarak yeni Köy Kanunu hazırlıkları tamamlanmalıdır.

- Valinin, il genel meclisine başkanlık etmesine son verilmiş ise de, il özel idaresindeki fazlasıyla sıra dışı konumu devam etmektedir. Valilerin il özel idaresinin faaliyetlerine müdahalesini azaltacak adımlar atılmalı, bu adımlar valilerin il özel idarelerinin ulusal birliği olan Vilayetler Birliğinndeki etkilerinin azaltılmasını da içermelidir.

- İçişleri Bakanlığı personelinin aynı zamanda Vilayetler Birliği’nde de görev yapması il özel idareleri ile Bakanlık arasındaki kurumsal mesafeyi azaltmakta, bu ikisi arasındaki ayrıksı ilişkiyi zedelemektedir.

- Belediyelerin ulusal birliği olan Türkiye Belediyeler Birliğine zorunlu üyelik uygulamasına son verilmesi hususu değerlendirilmelidir.

- Belediye ve il özel idarelerinin yurt dışı ilişsi kurabilmeleri için Bakanlıktan izin almaları uygulaması gözden geçirilmelidir.

- Özerklik Şartı’na konulan çekincelerin kaldırılması düşünülmelidir.

- 1997'deki Tavsiye Kararı’nda belirtilen; yerel yönetimlerin sınır ötesi işbirliği kurabilmesi, yabancıların yerel düzeyde kamu hayatına katılması, azınlık dillerinin ve ulusal azınlıkların korunması konularındaki sözleşmelere taraf olunması konusunda adım atılmalıdır.

\subsection{5(2014) sayılı Tavsiye (Recommendation 355(2014)}

Tavsiye (Congress, 2014a) 2009 yllında Doğu ve Güneydoğu’da aralarında o dönem Kongre Türkiye Ulusal Heyeti üyesi bir belediye başkanının da olduğu çok sayıda yerel seçilmişin bölücü terör örgütü üyeliği iddiasıyla tutuklanması üzerine alınmıştır. İlki 6 Ekim 2011, ikincisi ise 7 Aralık 2013 tarihlerinde düzenlenen iki ziyaret sonrası hazırlanan Rapora (Congress, 2014b) istinaden kabul edilen Tavsiyede tutuklu yargılanan yerel seçilmişlerin salıverilmesi talep edilmiştir. İzleme heyeti Türkiye’ye yaptığı her iki ziyarette de, cezaevlerine girme yetkisi olmadığı halde, Türk makamlarınca bir iyi niyet göstergesi olarak verilen özel izinlerle, tutuklu Kongre üyesini cezaevinde ziyaret ederek görüşmüştür. 
Bu tutuklamalara karşı Tavsiye kararından önce Kongre bünyesinde başka girişimler de olmuştur. Kongre Bürosu Mayıs 2010'da bu olaya ilişkin olarak endişelerin dile getirildiği "Türkiyede Tutuklanan Yerel Seçilmişler Hakkında Bildiri”(Congress, 2010) başlıklı bir bildiri yayınlamıştır. Bunu Mart 2013'te Kongre’nin yayınladığı yerel politikacılara yönelik geniş çaplı tutuklamaların yerel demokrasiyi zayıflattığının ifade edildiği "Türkiyede Yerel ve Bölgesel Politikacıların Durumu Hakkında Bildiri” (Congress, 2013a) başlıklı bir diğer bildiri takip etmiştir. Kongre tarafından, kurulduğu 1994 yılından 2019’a kadar toplam dört bildiri ${ }^{7}$ yayınlanmış olup bunların ilki 2013 yllında Türkiye’ye ilişkin olarak yayınlanan söz konusu bildiridir. Kongre ayrıca 2014 yllında aynı konuda bir karar (Congress, 2014c) daha almıştır. Karar'da Kongre, tutuklu Kongre üyesi ile birlikte tüm tutukluların durumunun sürekli izlenmesini ve Kongre Bürosu'nun her toplantısında bu konuyu gündemine almasını, ayrıca Kongre tarihinde ilk kez rastlanan bir uygulama olarak, Kongre’nin internet ana sayfasında tutuklu Kongre üyesinin fotoğrafıyla birlikte tutukluluğu hakkında bilgilerin yer alacağı bir bölüm oluşturulmasına karar vermiştir.

\subsection{7(2017) sayılı Tavsiye (Recommendation 397(2017)}

Türkiyede yerel yönetimlerin seçimle gelen organlarının veya bu organların üyelerinin kesin hükme kadar İçişleri Bakanı tarafından geçici bir tedbir olarak görevden uzaklaştırılabilmesine ilişkin Anayasảnın 127'nci maddesindeki hüküm Kongre tarafından en başından beri sürekli eleştirilen bir konudur. Bu şekilde görevden uzaklaştırılan tüm belediye başkanları yerine 5393 sayılı Belediye Kanunu’nun 45'inci maddesi (Belediye Kanunu, 2005) çerçevesinde ilgili belediye meclisi tarafından duruma göre yeni bir başkan veya başkan vekili seçilmekteydi. Ancak 45 'inci maddeye 2016 yılında eklenen fikra ile terör suçları iddiasıyla görevden uzaklaştırılan belediye başkanları bakımından ayrıma gidilmiş ve bunların yerine belediye meclisi tarafından başkan veya başkan vekili seçilmeyeceği, büyükşehir ve il belediyelerinde İçişleri Bakanı, diğer belediyelerde ise vali tarafından görevlendirme yapılacağı şeklinde ağırlaştırıcı bir hüküm getirilerek kamuoyunda kayyum ataması olarak bilinen uygulamanın hukuki dayanağı oluşturulmuştur. Kayyum atamalarının ilk uygulaması Diyarbakır’n Sur ve Silvan ilçe belediyelerine 8 Eylül 2016'da valilikçe yapılan görevlendirmelerle gerçekleştirilmiştir. 11 Eylül 2016'da İçişleri Bakanlığı’nca 28 belediyeye kayyum atandığı duyurulmuş ve 31 Mart 2019 seçimleri öncesi terör örgütü ile ilişkileri gerekçesiyle kayyum atanan belediye sayısı 93'ü bulmuştur (Alptekin ve İlhan, 2019). Kongre, büyük çoğunluğu Doğu ve Güneydoğu’daki görevden uzaklaştırmalar ve kayyum atamaları nedeniyle bir gerçeği-araştırma görevi düzenlenmesine karar vermiştir. Tavsiye’nin (Congress, 2017a) dayanağı Rapor (Congress, 2017b), 3-4 Ekim 2016 ve 18-20 Aralık 2016 tarihlerindeki iki ayrı izleme ziyaretindeki gözlemler çerçevesinde hazırlanmıştır.

Tavsiye kararında; Türkiye’nin kendisini ve kurumlarını korumak üzere uygun ve orantılı önlemler alma hakkının inkâr edilemeyeceği vurgulanmış ve yerel seçilmişlerin görevden uzaklaştırılması

7 Kongre’nin 1994-2019 döneminde yayınladığı diğer üç bildiriden ikisi 2014 yılında Ukrayna ile Rusya arasında yaşanan çatışma ve ayrılıkçı hareketler, üçüncüsü ise 2015 yılında Avrupa'ya göçmen akımı konularındadır (Congress, 2020). 
ve 3713 sayılı Terörle Mücadele Kanunu’nun uygulanması konusunda büyük ölçüde önceki tavsiyelerdeki eleştiriler yinelendikten sonra, Belediye Kanunu'nun 45'inci maddesine eklenen fıkranın yerel demokrasi bakımından yol açacağı sakıncalar üzerinde durulmuştur. Kanun'un 45'inci maddesine Eylül 2016'da eklenen değişikliğe kadar, Türkiye’nin de aralarında olduğu çoğu Avrupa devletindeki bir uygulama olan "görevden uzaklaştırılan belediye başkanının yerine belediye meclisince başkan seçilmesi uygulamasının” kanun dışı faaliyetlerin önlenmesi bakımından yeterli bir güvence olduğu ve bu nedenle sürdürülmesi gerektiği değerlendirmesinde bulunulmuştur.

Bu çerçevede, söz konusu Tavsiye kararında Kongre, özetle:

- Görevden alınan belediye başkanı yerine merkezi yönetim tarafından görevlendirme yapılmasına ilişkin hukuki düzenlemenin iptal edilerek bu tür durumlarda belediye meclislerinin belediye başkanı seçmesi uygulamasına geri dönülmesi,

- İçişleri Bakanlığı’nın eş başkanlık uygulamasını kanun dışı sayan 11 Kasım 2016 tarihli genelgesinin eş başkan atamasının yasal olarak kabulünü sağlayacak şekilde değiştirilmesi ve,

- Türk hukukunun, terörizm tanımının Avrupa standartlarıyla özellikle AİHM içtihatlarıyla uyumlu hale getirilmesini sağlayacak şekilde gözden geçirilmesi hususlarını dile getirmiştir.

Bu konuya ilişkin olarak Kongre tarafından başka bir karar (Congress, 2017c) daha alınmıştır. Söz konusu dönemde tutuklanan ve görevden alınanlar arasında Kongre Türkiye Ulusal Heyeti üyesi olan ve belediyesinde eş başkanlık da yapan bir belediye meclisi üyesi de bulunmaktaydı. Kongre bu ikinci kararında, yasal süreç sonuçlanıncaya kadar tutuklu Kongre üyesinin durumunun takip edilmesine ve konunun Kongre Bürosu gündeminde tutulmasına karar vermiş, ayrıca İnsan Hakları Komiserliği, Venedik Komisyonu, İşkenceyi Önleme Komitesi gibi Avrupa Konseyi kurumlarını göreve çağırmıştır. Söz konusu Karar doğrultusunda, Kongre Bürosu'nun internet sayfasında (Kongre ana sayfasında değil) tutuklulukla ilgili gelişmelerin yer aldı̆̆ bir bölüm oluşturulmuş, bir Kongre heyetinin tutuklu Kongre üyesini cezaevinde ziyaret ederek görüşmesi talebi ise Türk makamlarınca kabul edilmemiştir (Council of Europe, 2020c).

\subsection{Yılı Periyodik İzlemesi Kapsamında Gerçekleştirilen Ziyaretler}

Türkiye’ye yönelik 2019 yılı periyodik izleme görevi kapsamında Kongre İzleme Heyeti ülkemize ilk ziyaretini 1-3 Ekim 2019 tarihleri arasında gerçekleştirmiştir. Ziyaret kapsamında Ankara ve Diyarbakır'da, aralarında görevden alınan ve yerlerine kayyum atanan eski belediye başkanlarının da olduğu kişi ve kurum temsilcileriyle çeşitli görüşmelerde bulunulmuştur (Council of Europe, 2019a). 12-13 Kasım 2019 tarihleri arasındaki ikinci ziyaret kapsamında ise İzleme Heyeti, Ankara ve İstanbul'da çeşitli temaslar gerçekleştirmiştir (Council of Europe, 2019b). Kongre’nin 17 Mart 2020'de yapılması gerekirken Covid-19 Salgını sebebiyle ertelenen 38'inci Birleşimi'nde 
tavsiye kararına bağlanması planlanan 2019 izlemesi, bu nedenle henüz tamamlanamamıştır (Council of Europe, 2020d).

\section{Kongre'nin Türkiye'ye İlişkin Kararlarının Değerlendirilmesi}

Kongre’nin Şart’ın uygulanma durumunun değerlendirilmesine ilişkin olarak geliştirdiği izleme mekanizması sayesinde üye ülkelerdeki yerel ve bölgesel demokrasinin kapsamlı bir incelemesi yapılarak gelişmesinin önündeki engeller ortaya çıkarılmakta, Özerklik Şartı ve Bölgesel Demokrasi Çerçeve Belgesi ışı̆̆ında atılması gereken adımlar konusunda rehberlikte bulunulmaktadır. Mekanizma aynı zamanda, yerel ve bölgesel yönetimlerin başta merkezi yönetimlerin bu belgelere aykırı müdahaleleri olmak üzere haklarının korunması bakımından da bir güvence sağlama işlevi görmektedir.

Özerklik Şart’ı hükümlerinin üye ülke bakımından yükümlülük doğurması imzalama, onaylama ve yürürlüğe girme sürecinin tamamlanmasıyla gerçekleşmektedir. 15'inci maddede Şart'ın, imzacı ülke tarafından onaylandığının bildirildiği tarihten itibaren geçecek üç aylık süreyi izleyen ayın ilk günü yürürlüğe gireceği hükmü yer almaktadır. Ancak Şart’ın üye ülkelerdeki uygulanmasının gözetimine ilişkin Şart içeriğinde herhangi bir hüküm yer almamaktadır. Kongre, Şart’ın uygulanma durumunun izlenmesine ilişkin mekanizmanın oluşturulması çalışmalarını 1991'de başlatmıştır (Keleş, 1995, s.6). Başlangıçta, sadece Şart’ın yürürlük kazandığı üye ülkeler için informel bir denetim metodu benimsenmiş (Yeter, 1996, s.12) ise de ilerleyen dönemde Kongre’nin Avrupa Konseyi üyesi veya üye adayı tüm ülkelerde yerel ve bölgesel demokrasinin durumuna ilişkin rapor hazırlaması ilkesi kabul edilmiştir (Congress, 1996, para.6). Bu husus Kongre’nin, Şart’ın yürürlük kazanmadığı ülkeler hakkında da izleme faaliyeti sonrası tavsiye kararı alabilmiş olmasının anlaşılması bakımından önemlidir. Örneğin, Şart'in Arnavutluk, Belçika, Bosna-Hersek, Fransa, Gürcistan, İrlanda, Romanya, San Marino ve Sırbistan bakımından yürürlük kazandığı tarihten önce de Kongre'ce bu ülkelere yönelik izleme faaliyetlerine istinaden tavsiye kararları alınabilmiştir (Bkz. Tablo-2).

Bu çerçevede Şart, Türkiye tarafından 21 Kasım 1988 tarihinde imzalanmış ve 1 Nisan 1993'den geçerli olmak üzere Türkiye bakımından yürürlüğe girmiştir. Yürürlüğü takiben birkaç yıl sonra Türkiye Kongre tarafından izlemeye alınmış ve 29(1997) sayılı Tavsiye hazırlanmıştır. 1995 'teki Romanya izlemesi sayılmazsa, Kongre izleme mekanizması; ilk defa Türkiye ile birlikte Arnavutluk, İtalya ve Rusya hakkında işletilmiştir (Bkz. Tablo-2).

Türkiye hakkında temelde görevden alınan belediye başkanları nedeniyle başlatılan 1997 yılı izlemesi sonunda hazirlanan Raporda (Congress, 1997b, para.8) yer alan;

"Özgün bir yerel yönetimler reformu, bir bütün olarak ülke çapında eş zamanlı olarak uygulanabilirse, Doğu ve Güneydoğu’da yaşayanlar da dahil olmak üzere Türkiye’de demokratik hakların daha yüksek standartta kullanılmasına elverişli bir ortamın ortaya çıkarılmasını 
sağlayacaktır. Böylesi bir yerel yönetimler reformu, bazı durumlarda terörist faaliyetler için suistimal edilen gerilimlerin ortadan kaldırılmasına da katkıda bulunacaktır."

şeklindeki değerlendirme Kongre’nin bugüne kadar Türkiye'de yerel demokrasinin işleyişi hakkında aldığı tüm kararların ve hatta, Avrupa Konseyi’nin insan hakları alanında savunduğu değerlerin de etkisiyle, Türkiyede yerel demokrasinin güçlendirilmesi noktasında kendine biçtiği misyonun deyim yerindeyse omurgasını oluşturmuştur. Kongrede Türkiye hakkında kabul edilen metinlerde geçen ifadelerden yola çıkarak "yerel demokrasiyi güçlendirerek Güneydoğu sorununun çözümüne katkıda bulunmak" şeklinde tanımlayabileceğimiz bu misyonun doğal bir sonucu olarak, Kongre bünyesinde Türkiye’ye ilişkin olarak başlatılan tüm girişimlerin değişmez nedeni; Doğu ve Güneydoğu'daki yerel seçilmişlerin görevden uzaklaştırılması olmuştur. Zaten bu durum 2011 yılındaki Tavsiye’nin dayanağı Rapor’da da (Congress, 2011b, s.5-6); “Tüm bu izleme faaliyetlerinin genel amacı Türkiyede yerel demokrasinin durumunu incelemek olmakla birlikte ülkenin güneydoğusundaki ayrıksı durum bu izlemelerin odağındaki özel konuyu teşkil edegelmiştir” şeklindeki ifadelerle açıkça vurgulanmıştır.

Nitekim yerel ve bölgesel yönetimlerin seçimle gelen organlarının idari kararla görevden uzaklaştırılması Kongre'nin sadece Türkiye’de değil tüm üye ülkelerde eleştirdiği konuların başında gelmiştir.

Örneğin, 1995 yılında Romanyàya; 133 belediye başkanının (ülkedeki toplam belediye başkanlarının \%5'i) azledilmesi ${ }^{8}$, ilaveten 55 belediye başkanının (ülkedeki toplam belediye başkanlarının yaklaşık \%2'si) görevden uzaklaştırılması, 264 belediye başkanın istifa etmesi (ülkedeki toplam belediye başkanlarının \%9’u) ve yerel demokrasinin işleyişi bakımından kaygı verici diğer uygulamalar nedeniyle Kongre’ce bir gerçeği-araştırma görevi düzenlenmiştir (Congress, 1995, para.9/5).

Benzer şekilde, Bulgaristan'da periyodik izleme kapsamında 1998 yılında alınan tavsiye (Congress, 1998a) kararı ve dayanağı raporda (Congress, 1998b) hakkında soruşturma başlatılan belediye başkanının savcı tarafından geçici bir tedbir olarak görevden uzaklaştırılması uygulaması nedeniyle belediye başkanlarının yaklaşık \%5’inin görevi başında olmadığı belirtilerek uygulama eleştirilmiştir. 2011 yılındaki periyodik izlemeye ilişkin raporda (Congress, 2011c, para.80) ise; bu uygulamanın terk edildiği, 1999 yılından beri ilgili bakanın sadece mahkemeden belediye başkanının uzaklaştırılması için talepte bulunabilmesi şeklinde bir yöntemin benimsendiği belirtilerek duyulan memnuniyet ifade edilmiştir.

2003 yılında Belçika’nın Flaman Bölgesi’nde yaşanan bir olayda ise Kongre tarafından bir gerçeğiaraştırma görevi düzenlenmiştir. Flaman Bölgesi’nde, belediye meclisinin kendi içinden seçtiği belediye başkanının İçişleri Bakanı’nca onaylanması uygulaması çerçevesinde üç belediye başkanı, seçimleri onaylanmadığı için göreve başlayamamıştır. Alınan tavsiye kararında (Congress, 2008)

8 Çalışmada, azil ya da azletme ifadesi geçici bir tedbir olan görevden uzaklaştırmadan farklı olarak görevin tümüyle sona erdirilmesi anlamında kullanılmıştır. 
bu uygulamanın Şart’a aykırı olduğu ve Flaman İçişleri Bakanı tarafından onaylama sisteminin iptal edilmesi gerektiği belirtilmiştir.

Yine 2018 yılında Moldova'da aynı zamanda Kongre’nin Bölgeler Meclisi Başkan Yardımcısı da olan başkent Kişinev’in belediye başkanının yolsuzlukla mücadele savcısının girişimiyle görevden uzaklaştırılması (Congress, 2017d) nedeniyle Kongre tarafından bir gerçeği-araştırma görevi düzenlenmiş ve bu konudaki eleştiri ve önerilerin yer aldığı tavsiye kararı (Congress, 2018) kabul edilmiştir. 2002 yılında Moldova’nın özerk bölgesi Gagavuzya’da, bölge valisinin (bashkan-başkan) görevden alınması için düzenlenen kanuna aykırı halkoylaması nedeniyle de Kongre’ce bir gerçeğiaraştırma görevi düzenlenmiş, alınan tavsiye kararında (Congress, 2002) bu konudaki eleştiriler dile getirilmiştir. Son olarak; Moldova’ya yönelik 2005 yılındaki periyodik izleme kapsamında, ayrıntıları izleme raporunda (Congress, 2005c) belirtilen muhalefet partilerine mensup bazı belediye başkanlarının görevden uzaklaştırılması, azledilmesi veya istifaya zorlanması konusu izlemeye ilişkin tavsiye kararında eleştirilen konular arasında yer almıştır (Congress, 2005d).

Aşağıda Tablo-2'de ülkeler Özerklik Şartı’nın yürürlük kazandığg tarih esas alınarak ve kıyaslama yapılabilmesi için tarafımızdan geliştirilen dörtlü bir gruplandırma içinde sıralanmış olup her bir ülke hakkında Kongre tarafından kuruluşundan bugüne kadar izleme görevine istinaden alınan tavsiye kararları toplu şekilde gösterilmektedir. Buna göre Türkiye, eski Doğu Bloku ülkesi Moldova'nın ardından en çok izlemeye alınan ve hakkında en çok tavsiye kararı alınan ülkedir. Tablo-2'de ayrıca, ülkelerin izlenme sıklığında da bir yeknesaklığın bulunmadığı, ilgili tavsiye kararlarından (Congress, 2011d; Congress, 2012; Congress, 2013b; Congress, 2014d) anlaşıldığ kadarıyla sorunsuz işleyen bir yerel ve bölgesel demokrasiye sahip olmadıkları halde Almanya, Avusturya, İngiltere, İspanya gibi ülkelerin daha uzun aralıklarla izlemeye alındığı, buna karşılık yerel demokrasinin görece yeni filizlenmekte olduğu eski Doğu Bloku ülkelerinin daha sık aralıklarla izlendiği görülmektedir. Türkiye ise eski Doğu Bloku ülkelerinden de sık olarak, birisi henüz tamamlanıp tavsiye kararına bağlanmadığı için Tablo-2'de yer almayan, toplam yedi izleme görevine konu edilmiştir. Bunda Kongre’nin Türkiye’ye karşı ayrımcı bir tutum içerisinde olmasından ziyade Türkiye’de görevden uzaklaştırma uygulamasına son dönemde daha sık başvurulmasının ve Türkiye’deki uygulamalara ilişkin olarak Kongre’ye yapılan şikâyetlerin sayıca fazlalığının payı büyüktür.

Tablo-2: Kongre’nin Üye Ülkelerde Periyodik İzleme veya Gerçeği-Araştırma Görevlerine İstinaden Aldığı Tavsiye Kararları (1994-2019)

\begin{tabular}{|c|c|c|c|c|}
\hline & Ülkeler & $\begin{array}{l}\text { Şart'ın Yürürlük } \\
\text { Tarihi }\end{array}$ & Kararlar & $\begin{array}{c}\text { Toplam Karar } \\
\text { Sayısı }\end{array}$ \\
\hline \multirow{6}{*}{ 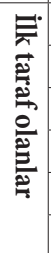 } & Almanya & $01 / 09 / 1988$ & R64(1999)1, R320(2012) & 2 \\
\hline & Avusturya & $01 / 09 / 1988$ & R302(2011) & 1 \\
\hline & Danimarka & 01/09/1988 & R164(2005), R350(2013) & 2 \\
\hline & GKRY & $01 / 09 / 1988$ & R96(2001), R178(2005), R389(2016) & 3 \\
\hline & Lihtenştayn & 01/09/1988 & R196(2006), R416(2018) & 2 \\
\hline & Lüksemburg & $01 / 09 / 1988$ & R172(2005), R380(2015) & 2 \\
\hline
\end{tabular}




\begin{tabular}{|c|c|c|c|c|}
\hline \multirow{11}{*}{ 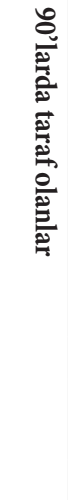 } & İspanya & $01 / 03 / 1989$ & R121(2002), R336(2013) & 2 \\
\hline & Norveç & $01 / 09 / 1989$ & R141(2003), R374(2015) & 2 \\
\hline & İsveç & $01 / 12 / 1989$ & R163(2005), R357(2014) & 2 \\
\hline & Yunanistan & $01 / 01 / 1990$ & R109(2002), R247(2008), R372(2015) & 3 \\
\hline & İtalya & 01/09/1990 & R35(1997), R337(2013), R404(2017) & 3 \\
\hline & Portekiz & $01 / 04 / 1991$ & R127(2003), R323(2012) & 2 \\
\hline & Hollanda & $01 / 07 / 1991$ & R55(1999), R352(2014) & 2 \\
\hline & İzlanda & $01 / 07 / 1991$ & R283(2010), R402(2017) & 2 \\
\hline & Finlandiya & $01 / 10 / 1991$ & R66(1999), R311(2011), R396(2017) & 3 \\
\hline & TÜRKIYE & 01/04/1993 & $\begin{array}{l}\text { R29(1997), R176(2005), R229(2007), 301(2011), } \\
\text { 355(2014), 397(2017) }\end{array}$ & 6 \\
\hline & Malta & 01/01/1994 & R122(2002), R305(2011), R400(2017) & 3 \\
\hline \multirow{19}{*}{ 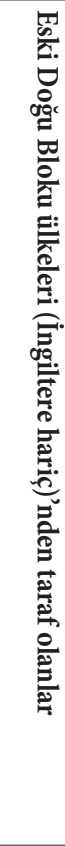 } & Polonya & 01/03/1994 & R120(2002), R373(2015), R431(2019) & 3 \\
\hline & Macaristan & 01/07/1994 & R116(2002), R341(2013) & 2 \\
\hline & Estonya & $01 / 04 / 1995$ & R81(2000), R294(2010), R401(2017) & 3 \\
\hline & Bulgaristan & $01 / 09 / 1995$ & R45(1998), R310(2011) & 2 \\
\hline & Slovenya & 01/03/1997 & R308(2011), R421(2018) & 2 \\
\hline & Letonya & 01/04/1997 & R47(1998), R257(2008), R317(2011), R412(2018) & 4 \\
\hline & Makedonya & 01/10/1997 & R82(2000), R217(2007), R329(2012) & 3 \\
\hline & Ukrayna & $01 / 01 / 1998$ & R48(1998), R102(2001), R348(2013) & 3 \\
\hline & Hirvatistan & $01 / 02 / 1998$ & R46(1998), R226(2007), R391(2016) & 3 \\
\hline & Moldova & 01/02/1998 & $\begin{array}{l}\text { R38(1998), R84(2000), R110(2002), R179(2005), } \\
\text { R322(2012), R411(2018), R436(2019) }\end{array}$ & 7 \\
\hline & Romanya & $01 / 05 / 1998$ & R12(1995), R300(2011) & 2 \\
\hline & İngiltere (UK) & 01/08/1998 & R49(1998), R353(2014) & 2 \\
\hline & Rusya & $01 / 09 / 1998$ & R30(1997), R143(2004), R297(2010), R440(2019) & 4 \\
\hline & Çekya & 01/09/1999 & R77(2000), R319(2012) & 2 \\
\hline & Litvanya & 01/10/1999 & R87(2001), R321(2012), R420(2018) & 3 \\
\hline & Slovakya & $01 / 06 / 2000$ & R88(2001), R204(2006), R387(2016) & 3 \\
\hline & Arnavutluk & $01 / 08 / 2000$ & R28(1997), R201(2006), R349(2013) & 3 \\
\hline & Ermenistan & $01 / 05 / 2002$ & R140(2003), R351(2014) & 2 \\
\hline & Azerbaycan & $01 / 08 / 2002$ & R126(2003), R326(2012) & 2 \\
\hline \multirow{11}{*}{ 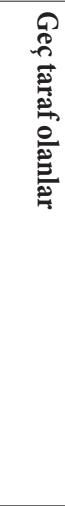 } & İrlanda & $01 / 09 / 2002$ & R97(2001), R342(2013) & 2 \\
\hline & Bosna-Hersek & $01 / 11 / 2002$ & $\begin{array}{l}\text { R103(2001), R202(2006), R324(2012), R356(2014), } \\
\text { R442(2019) }\end{array}$ & 5 \\
\hline & Belçika & $01 / 12 / 2004$ & R131(2003), R258(2008), R366(2014), R409(2017) & 4 \\
\hline & Gürcistan & $01 / 04 / 2005$ & R157(2004), R334(2013), R426(2018) & 3 \\
\hline & İsviçre & $01 / 06 / 2005$ & R285(2010), R407(2017) & 2 \\
\hline & Fransa & $01 / 05 / 2007$ & R78(2000), R384(2016) & 2 \\
\hline & Sirbistan & $01 / 01 / 2008$ & R104(2001), R316(2011), R403(2017) & 3 \\
\hline & Karadağ & $01 / 01 / 2009$ & R293(2010), R379(2015) & 2 \\
\hline & Andorra & $01 / 07 / 2011$ & R415(2018) & 1 \\
\hline & Monako & $01 / 05 / 2013$ & R417(2018) & 1 \\
\hline & San Marino & $01 / 02 / 2014$ & R63(1999), R418(2018) & 2 \\
\hline \multicolumn{4}{|c|}{ Toplam } & 124 \\
\hline
\end{tabular}


Açılklamalar:

1) R: Recommendation

2) Tablodaki her bir ülkeye ait tavsiye kararı bilgileri Kongre internet sayfasında https://www.coe.int/en/web/ congress/adopted-texts (Erişim tarihi: 11 Mayıs 2020)'nden erişilen tüm tavsiye kararları içerisinden izleme veya gerçeği-araştırma görevlerine istinaden alınanlar seçilerek oluşturulmuş, Kongre’nin üye ülkelere ilişkin olarak aldığı farklı konulardaki tavsiye kararları (örneğin seçim gözlem görevine istinaden alınan tavsiye kararları) ve mükerrer kayitlar elenmiştir. Buradan elde edilen bilgiler ayrıca https://www.coe.int/en/web/congress/congressreports\#\{\%225.421.3415\%22:[]\} (Erişim tarihi: 20.05.2020)'deki bilgilerle karşılaştırllarak kontrol edilmiştir.

3) Şart'ın ülkeler bakımından yürürlük tarihi ile ilgili bilgiler; Chart of Signatures and Ratifications of Treaty 122-European Charter of Local Self-Government, https:/www.coe.int/en/web/conventions/full-list/-/conventions/ treaty/122/signatures?p_auth=YQyCRehu (Erişim tarihi: 26.05.2020)'den alınmıştır.

Delillerin ortadan kaldırılma olasılığı da olsa ve İçişleri Bakanı bu yetkisini kullanmasa bile, yerel yönetimlerin organlarının görevden uzaklaştırılmasına ilişkin yetkinin Anayasamızda bulunması yerel demokrasi ve yerel özerkliğe ters düşmektedir (Keleş, 1996, s.32). Bununla birlikte, Türkiye'de vesayet yetkisi kapsamında hakkında işlem yapılan, görevden uzaklaştırılan veya yerlerine kayyum atananların büyük çoğunluğunu HDP çizgisinde siyaset yapanlar oluştursa da sadece onlardan oluşmadığı bilinmektedir (İçişleri Bakanlığı, 2020; Keleş ve Özgül, 2017, s.307-310; Yıldırım, 2017). Bu çerçevede Kongre’nin Türkiye’deki tüm görevden uzaklaştırmalar karşısındaki tavrı her zaman aynı olmamış, haklarında işlem tesis edilen farklı partilerden yerel seçilmişler bugüne kadar Kongre’nin gündemine gelmemiştir. Örneğin; 2010 yılında o dönem MHP’den seçilen ve sonrasında yolsuzluk iddiasıyla hakkında başlatılan soruşturma nedeniyle Türkiye'nin beşinci büyük kenti Adana’nın Büyükşehir Belediye Başkanı’nın görevinden uzaklaştırılmasına (haberturk.com, 2010) Kongre hiçbir tepki vermediği gibi bu tarihten sonraki izlemelerde de bu konuya hiç değinmemiştir. Oysa bu olaydan üç yıl önce Sur ilçesi belediye başkanının görevden uzaklaştırılması üzerine bir gerçeği-araştırma görevi düzenlenmişti.

Kongre bünyesinde Türkiye’ye yönelik olarak bugüne kadar kabul edilen metinler incelendiğinde Kongre’nin, Türkiye’de görevden uzaklaştırma uygulamasına kategorik olarak karşı bir duruş sergilemek yerine tepki verirken seçici davrandığı görülmektedir. Kanaatimizce, görevden alınan tüm yerel seçilmişler içinde sadece belediye başkanlarını, belediye başkanları içerisinde Doğu ve Güneydoğu'da HDP çizgisinde olanları ve hatta bunlar içinde de Kongre üyesi birinin simgeleştirilmesiyle görevden uzaklaştırmanın yanlışlı̆̆ı konusuna ulusal ve uluslararası platformlarda daha etkili şekilde dikkat çekileceği öngörüsüyle hareket edilmektedir. Nitekim Kongre’nin 2013 yılında yerel seçilmişlerin tutuklanması ve görevden uzaklaştırılması nedeniyle yayınladığı bildiride bu kişiler arasında yer alan Kongre üyesinin “Türkiyede tutuklanan ve görevden alınan tüm yerel seçilmişlerin simgesi olarak kabul edildiği” (Congress, 2013a, para.4/b) şeklindeki ifade bu öngörünün yansımasıdır. 2018 yılında Kişinev Belediye Başkanı ve Kongre Bölgeler Meclisi Başkan Yardımcısı’nın görevden uzaklaştırılmasında gündeme gelmeyen sembolleştirme yaklaşımı Türkiye özelinde bugün de 2016'daki ilk kayyum atama dalgasında görevden uzaklaştırılan belediye eş başkanı ve Kongre üyesi üzerinden sürdürülmektedir. Kongre bu yaklaşımının, Kongre üyeleri arasında dayanışmanın güçlendirilmesi ve Türkiyede yerel demokrasinin geliştirilmesi çalışmalarında kolaylaştırıcı bir faktör olarak rol oynayacağını 
değerlendiriliyor olabilir. Ancak Türkiye içinde, HDP siyasetinin Özerklik Şartı’yla doğrudan ilgisi olmayan unsurlar içeren demokratik özerklik söyleminin kamuoyunun Şart’a yönelik algısını olumsuz etkilediği ve bu alanda atılabilecek adımları zorlaştırdığı (Sobacı, 2015, s.28) hususu dikkate alındığında, anılan yaklaşımın beklenen olumlu etkiyi yaratmayacağı göz ardı edilmemelidir.

Görevden uzaklaştırma konusunda önceki Kongre tavsiyelerinin aksine gelişmelere rağmen, 397(2017) sayılı son Tavsiye Kararında (Congress, 2017a) Kongre-Türkiye ilişkilerinde gerilimin azaltılması yönünde belirtiler bulunmaktadır. Kongre'nin bugüne dek ilk defa, Türkiye’nin kendisini korumak üzere önlem alma hakkını teyit etmesi, görevden uzaklaştırma tedbirinden "çoğu Avrupa devletindeki bir uygulama" olarak bahsetmesi ve görevden uzaklaştırılan belediye başkanının yerine kayyum atanmayıp belediye meclisince başkan seçilmesi uygulamasının devam ettirilmesini istemesi Türkiye’ye karşı tutumdaki yumuşamanın yansımaları olarak görülmelidir. Türkiye’nin hassasiyetlerini göz ardı etmeyen bu tutumun 2019 yılı periyodik izlemesine ilişkin tavsiye kararına da yansıması sürpriz olmayacaktır.

\section{Sonuç}

Ülkemizde özellikle 2000’lerin başındaki hızlı reform döneminde yenilenen mevzuatla yerel demokrasi alanında olumlu yönde bir dönüşüm yaşanırken hayata geçirilen pek çok düzenlemeyle Özerklik Şartı çerçevesinde Kongre’nin eleştiri ve tavsiyelerinin karşılanmasına yönelik bazı iyileştirmeler kaydedilmiştir. Çoğu 2004-2005 yılları arasında gerçekleştirilmiş olan bu mevzuat düzenlemelerinden bazılarının genel gerekçelerinde Avrupa Yerel Yönetimler Özerklik Şartı’na uyumun arttırlmasindan bahsedilmektedir (TBMM, 2020a; TBMM, 2020b). Bu mevzuatla yerel yönetim meclislerinin güçlendirilmesi ve üyelerinin mali haklarının iyileştirilmesi, yerel yönetimlerin iç örgütlenmede ve personel istihdamında yetkilendirilmesi, ulusal ve uluslararası birliklere üye olunabilmesi, yerel yönetimleri ilgilendiren konularda kurulan ulusal birlikler vasıtasıyla danışma mekanizmasının geliştirilmesi, yerel yönetimler üzerindeki idari vesayetin azaltılması, öz gelir artı̧̧ biçiminde olmamakla birlikte merkezden pay dağıtım sisteminde yapılan değişikle gelirlerinin arttırılması, il özel idarelerinin yapısında valinin konumunu da içerecek şekilde değişiklikler yapılması (Aydın ve Taş, 2011; Eryiğit, 2015; Dursun, 2007; İçişleri Bakanlığı, 2017, s.39-41; Zorluoğlu, 2011, s.10-15) gibi Kongre kararlarında eleştirilen bazı başlıklarda ilerleme kaydedilmiştir. Kamu Yönetimi Temel Kanunu Tasarısı'yla başlatılan devrim niteliğindeki yerel yönetimleri merkezi yönetim karşısında genel görevli kılacak ve yerindenliği hayata geçirecek girişim (Haktankaçmaz, 2011, s.84-85) ise, o dönemde devlet içindeki iktidar mücadelesi nedeniyle başarıya ulaşmamıștır.

Kongre'nin Türkiye'de yerel demokrasinin geliştirilmesi çalışmalarında belirleyici etkisinin yüksek olduğu bu dönemden sonra, 2010'dan itibaren çok sayıda yerel seçilmişin tutuklanması ve görevden uzaklaştırılmasının tetiklemesi ve sonrasında ardı ardına gelen izleme ziyaretleri, bildiriler, kararlar ve Kongre tarihinde ilk kez başvurulan uygulamalarla ilişkilerde gerilimli 
bir sürece girilmiştir. Kongre’nin yerel demokrasinin güçlendirilmesine rehberlik anlamındaki etkisinin göreli olarak azaldığı bu gerilimli sürecin ortaya çıkışında, ülkemizde Kongre’nin başından beri ısrarla eleştirdiği yerel seçilmişlerin görevden uzaklaştırılması uygulamasının sıklaşması, reform hızının yavaşlaması ve hatta yerel yönetimler alanında 2004-2005 yıllarındaki olumlu gelişmelerin aksi istikamette düzenlemelerin gerçekleştirilmesi kadar Kongre’nin bu gelişmeler karşısında benimsediği tutum da etkili olmuştur.

Kongre’nin başından beri Türkiye'de yerel demokrasiye bakışının odağında yer alan ve karşı tutumunu 2010'dan itibaren kademeli olarak sertleştirdiği Doğu ve Güneydoğu'daki yerel seçilmişlerin görevden uzaklaştırılması uygulaması zaman içinde ilişkilerde neredeyse tek belirleyici hale gelmiştir. Bununla birlikte Kongre’nin Türkiye'de yerel demokrasinin durumuna bakışının omurgasını oluşturan görüşlerin yer aldığı 29(1997) sayılı Tavsiye’nin dayanağı Rapor'da (Congress, 1997b, para.6) “İzleme Heyeti’nin, ülkenin Doğu ve Güneydoğusu’nda yaşayanların durumu ya da köylerin boşaltıldığı yahut belediye başkanı ve meclis üyelerinin taciz edildiği veya görevden alındığı iddialarının soruşturulmasına değil Türkiye’de yerel demokrasinin işleyişiyle ilgili genel konulara odaklanacağının" belirtilmiş olması dikkat çekicidir.

Söz konusu Rapor’da bu tercihin nedenine ilişkin olarak; "anılan konuların AİHM, İnsan Hakları Komiserliği, İşkencenin Önlenmesi Komitesi başta olmak üzere Avrupa Konseyi bünyesinde insan haklarının korunması amacıyla oluşturulmuş ihtisas kuruluşlarının görev alanında kalması ve bu tür iddiaların zaten bu kuruluşlarca incelenmekte olması" şeklinde yapılan açıklamanın bugün Kongre-Türkiye ilişkilerinde yaşanan tıkanıklığın aşılması bakımından yol gösterici olabileceği değerlendirilmektedir. Zira Kongre’nin zaman zaman kendisinin de göreve çağırdığı insan haklarının korunması alanında uzmanlaşmış Konsey bünyesindeki kurumların bu konuda yapacağı çalışmaları öncelemesi hem sorunun çözümüne yeni bir perspektif getirebilecek hem de Kongre’nin Türkiyede yerel demokrasinin işleyişini aksatan diğer konulara daha fazla eğilebilmesine imkân sağlayabilecektir.

Türkiyede yerel demokrasinin işleyişini aksatan sorunların en başında yerel seçilmişlerin idari kararla görevden uzaklaştırılmasının geldiği tartışmasızdır ancak yegâne sorun bu değildir. Kongre kararlarında da belirtildiği üzere yerel yönetimlerde öz gelir azlığı, vatandaş katılımının yetersizliği, merkezi yönetimin görevden uzaklaştırma dışındaki diğer vesayet uygulamaları gibi pek çok sorun bugüne kadar görevden uzaklaştırma sorununun gölgesinde kalmış ve yeterli ilgiyi görememiştir. Dahası, 6360 sayılı Kanunla (On Dört İlde, 2012) gerçekleştirilen ölçek reformu ve 30 büyükşehirde il özel idarelerinin tüzel kişiliğinin sona erdirilmesi veya Yatırım İzleme ve Koordinasyon Başkanlıklarının (YİKOB) kurulması gibi Türkiye'de yerel yönetim sisteminde bir kırılmayı ve merkezileşme eğilimini işaret eden (Keleş ve Özgül, 2017, s.303-304) konularda Kongre henüz bir görüş dahi belirtememiştir.

Buna karşılık Türkiye tarafında da yerel yönetimlerin idari ve mali özerkliğine ilişkin asgari standartları belirleyen ve ülkemiz bakımından bazı çekincelerle yürürlüğe giren Özerklik Şartı’nın ötesinde Yllmaz (2018, s.670)'in belirttiği gibi Şart’ın denetim mekanizmasının, bir diğer 
deyişle Kongre’nin, ortaya koyduğu uygulama ilkelerinin dikkate alınması ve bu yönde çalışmalar yapılması yerel demokrasinin geliştirilmesi bakımından gereklidir.

\section{Kaynakça}

Alptekin, H. ve İlhan, B. (2019). 5 Soru: Diyarbakır, Mardin, Van Büyükşehir Belediye Başkanlarının Görevden Uzaklaştırılması, SETA, https://www.setav.org/5-soru-diyarbakir-mardin-van-buyuksehir-belediyebaskanlarinin-gorevden-uzaklastirilmasi/ (Erişim tarihi: 14.05.2020).

Avrupa Konseyi (2017). Avrupa Konseyinin Bölgesel Demokrasiyle İçin Başvuru Çerçeve Belgesi, https:// rm.coe.int/168.071.9195 (Erişim tarihi: 07.05.2020).

Aydın, A. H. ve Taş, İ. E. (2011). Küreselleşme Sürecinde Türkiye'de Yerel Yönetim Yasalarında Yerel Özerklik. Ahmet Kesik ve Hasan Canpolat (der.), Küreselleşme ve Kamu Yönetiminde Dönüşüm içinde (29-51), Ankara: Seçkin Yayıncılık.

Belediye Kanunu (2005). https://www.mevzuat.gov.tr/MevzuatMetin/1.5.5393.pdf (Erişim tarihi: 03.06.2020).

Büyükşehir Belediyesi Sınırları İçerisinde İlçe Kurulması ve Bazı Kanunlarda Değiş̧iklik Yapılması Hakkında Kanun (2008). https://www.mevzuat.gov.tr/MevzuatMetin/1.5.5747.pdf (Erişim tarihi: 02.06.2020).

Committee of Ministers (1994). CM/Resolution 94(3) relating to the Setting up of the Congress of Local and Regional Authorities of Europe, https://search.coe.int/cm/Pages/result_details. aspx?ObjectId=090.000.16804efe6c (Erişim tarihi: 30.05.2020).

Congress (1995). Congress of Local and Regional Authorities of Europe, Recommendation 12(1995) on Local Democracy in Romania, https://rm.coe.int/090.000.168071aa75 (Erişim tarihi: 20.05.2020).

Congress (1996). Congress of Local and Regional Authorities of Europe, Resolution 31(1996) on Guiding Principles for the Action of the Congress when Preparing Reports on Local and Regional Democracy in Member States and Applicant States, https://rm.coe.int/CoERMPublicCommonSearchServices/ DisplayDCTMContent?documentId=090.000.1680719012 (Erişim tarihi: 23.05.2020).

Congress(1997a). Congress ofLocaland Regional Authorities ofEurope, Recommendation 29(1997)on theStateof Local and Regional Democracy in Turkey, https://rm.coe.int/CoERMPublicCommonSearchServices/ DisplayDCTMContent?documentId=090.000.1680719b5b (Erişim Tarihi: 24.12.2019).

Congress (1997b). Congress of Local and Regional Authorities of Europe, CG(4)3 Report on the State of Local and Regional Democracy in Turkey - Part II, https://search.coe.int/congress/Pages/result_details. aspx?ObjectId=090.000.16807198f3 (Erişim tarihi: 06.01.2019).

Congress (1998a). Congress of Local and Regional Authorities of Europe, Recommendation 45(1998) on the Situation of Local and Regional Self-Government in the Republic of Bulgaria, https://rm.coe. int/090.000.1680719327\#P4_24 (Erişim tarihi: 20.05.2020).

Congress (1998b). Congress of Local and Regional Authorities of Europe, CG(5)3 on Report on the situation of local and regional self-government in the Republic of Bulgaria-Part II, https://search.coe.int/congress/ Pages/result_details.aspx?ObjectId=090.000.1680718e1e (Erişim tarihi: 26.05.2020).

Congress (2001). Congress of Local and Regional Authorities of Europe, CG/INST(8)27 Information Report on Local and Regional Democracy in Turkey - Follow up to Recommendation 29(1997), https:// search.coe.int/congress/Pages/result_details.aspx?ObjectId=090.000.1680719d14 (Erişim tarihi: 10.05.2020).

Congress (2002). Congress of Local and Regional Authorities of Europe, Recommendation 110(2002) on Local and Regional Democracy in Moldova, https://rm.coe.int/090.000.1680719acb (Erişim tarihi: 20.05.2020). 
Congress, (2005a). Congress of Local and Regional Authorities of Europe, Recommendation 176(2005) on Local and Regional Democracy in Turkey, https://search.coe.int/congress/Pages/result_details. aspx?ObjectId=090.000.168071a590 (Erişim tarihi: 20.05.2020).

Congress (2005b). Congress of Local and Regional Authorities of Europe, CG(12)25 Local and Regional Democracy in Turkey-Part II, https://search.coe.int/congress/Pages/result_details. aspx?ObjectId=090.000.1680719da4 (Erişim tarihi: 26.12.2019).

Congress (2005c). Congress of Local and Regional Authorities of Europe, CPL(12)9 on Local Democracy in Moldova-Part II, https://rm.coe.int/168071936a (Erişim tarihi: 26.05.2020).

Congress (2005d). Congress of Local and Regional Authorities of Europe, Recommendation 179(2005) on Local Democracy in Moldova, https://rm.coe.int/090.000.168071a450 (Erişim tarihi: 20.05.2020).

Congress (2007). Congress of Local and Regional Authorities of Europe, Recommendation 229(2007) on Local Democracy in Turkey, https://rm.coe.int/090.000.1680719b53 (Erişim tarihi: 20.05.2020).

Congress (2008). Congress of Local and Regional Authorities of Europe, Recommendation 258(2008) on Local democracy in Belgium: non-appointment by the Flemish authorities of three mayors: within a reasonable timeframe, https://rm.coe.int/090.000.168071ab5b (Erişim tarihi: 20.05.2020).

Congress (2010). Congress of Local and Regional Authorities of Europe, Bureau of the Congress(2010)Declaration on elected representatives detained in Turkey, https://rm.coe.int/090.000.168071996b (Erişim tarihi: 10.05.2020).

Congress (2011a). Congress of Local and Regional Authorities of Europe, Recommendation 301(2011) on Local and Regional Democracy in Turkey, https://search.coe.int/congress/Pages/result_details. aspx?ObjectId=090.000.168071a62c (Erişim tarihi: 20.05.2020).

Congress (2011b). Congress of Local and Regional Authorities of Europe, CG(20)6 on Local and Regional Democracy in Turkey. https://rm.coe.int/168071a9f7\#_ftnref15 (Erişim tarihi: 06.01.2019).

Congress (2011c). Congress of Local and Regional Authorities of Europe, CG(21)14 on Local and Regional Democracy in Bulgaria, https://search.coe.int/congress/Pages/result_details. aspx?ObjectId=090.000.1680718cc4 (Erişim tarihi: 26.05.2020).

Congress (2011d). Congress of Local and Regional Authorities of Europe, Recommendation 302(2011) on Local and Regional Democracy in Austria, https://rm.coe.int/090.000.1680719098 (Erişim tarihi: 20.05.2020).

Congress (2012). Congress of Local and Regional Authorities of Europe, Recommendation 320(2012) on Local Democracy in Germany https://rm.coe.int/090.000.168071a85b (Erişim tarihi: 20.05.2020).

Congress (2013a). Congress of Local and Regional Authorities of Europe, Declaration 1(2013) on The Situation of Local and Regional Politicians in Turkey, https://rm.coe.int/090.000.168071a851 (Erişim tarihi: 10.05.2020).

Congress (2013b). Congress of Local and Regional Authorities of Europe, Recommendation 336(2013) on Local and Regional Democracy in Spain, https://rm.coe.int/090.000.168071add5 (Erişim tarihi: 20.05.2020).

Congress (2014a). Congress of Local and Regional Authorities of Europe, Recommendation 355(2014) on the SituationofLeylaGuvenandOtherLocalElectedRepresentativesinDetentionin Turkey, https://rm.coe.int/ CoERMPublicCommonSearchServices/DisplayDCTMContent?documentId=090.000.168071a40e (Erişim tarihi: 20.05.2020).

Congress (2014b). Congress of Local and Regional Authorities of Europe, CG(26)6Final The situation of Leyla Güven and Other Local Elected Representatives in Detention in Turkey, https://search.coe.int/ 
congress/Pages/result_details.aspx?ObjectId=090.000.16807196c9\#_Toc383689306 (Erişim Tarihi: 02.06.2020).

Congress (2014c). Congress of Local and Regional Authorities of Europe, Resolution 367(2014) on the Situation of Leyla Guven and Other Local Elected Representatives in Detention in Turkey, https:// search.coe.int/congress/Pages/result_details.aspx?ObjectId=090.000.16807196c9\#_ftnref4 (Erişim tarihi: 04.05.2020).

Congress (2014d). Congress of Local and Regional Authorities of Europe, Recommendation 353(2014) on Local and Regional Democracy in the United Kingdom, https://rm.coe.int/090.000.1680719267 (Erişim tarihi: 20.05.2020).

Congress (2017a). Congress of Local and Regional Authorities of Europe, Recommendation 397(2017) on Fact-finding Mission on the Situation of Local Elected Representatives in Turkey, https://rm.coe. int/16806fbf0d (Erişim tarihi: 09.01.2019).

Congress (2017b). Congress of Local and Regional Authorities of Europe, CG32(2017)13final Fact-finding Mission on the Situation of Local Elected Representatives in Turkey, https://rm.coe.int/16806fbfod (Erişim tarihi: 02.06.2020).

Congress (2017c). Congress of Local and Regional Authorities of Europe, Resolution 416(2017) on Factfinding Mission on the Situation of Local Elected Representatives in Turkey, https://rm.coe. int/090.000.1680703e9a (Erişim tarihi: 15.05.2020).

Congress (2017d). Congress of Local and Regional Authorities of Europe, Resolution 420(2017) on Local Democracy in the Republic of Moldova: Clarification of the Conditions Surrounding the Suspension of the Mayor of Chișinău, https://search.coe.int/congress/Pages/result_details. aspx?ObjectId=090.000.1680760bfe (Erişim tarihi: 20.05.2020).

Congress (2018). Congress of Local and Regional Authorities of Europe, Recommendation 411(2018) on Fact-finding Mission on the Situation of Local Elected Representatives in the Republic of Moldova Suspension of the General Mayor of Chișinău, https://rm.coe.int/090.000.168098add8 (Erișim tarihi: 20.05.2020).

Congress (2020). Congress of Local and Regional Authorities of Europe, Declarations of the Congress, https:// www.coe.int/en/web/congress/declarations-of-the-congress (Erişim tarihi: 16.05.2020).

Council of Europe (1985). European Charter of Local Self-Government, https://www.coe.int/en/web/ conventions/full-list/-/conventions/rms/090.000.168007a088 (Erişim tarihi: 02.06.2020).

Council of Europe (2015). The Congress of Local and Regional Authorities of The Council of Europe, https:// rm.coe.int/1680719f4d (Erişim tarihi: 08.05. 2020).

Council of Europe (2018). Rules and Procedures of the Congress of Local and Regional Authorities of the Council of Europe, https://rm.coe.int/rules-and-procedures-of-the-congress-of-local-and-regionalauthorities/16809208a9 (Erişim tarihi: 06.05.2020).

Council of Europe (2019a), News 2019-Congress Carried out a Monitoring Visit to Turkey, https://www. coe.int/en/web/congress/-/congress-to-carry-out-a-monitoring-visit-to-turkey (Erişim tarihi: 16.05.2020).

Council of Europe (2019b). News 2019-Second Part of the Monitoring Visit to Turkey, https://www.coe.int/ en/web/congress/-/the-congress-carries-out-the-second-part-of-the-monitoring-visit-to-turkey (Erişim tarihi: 16.05.2020).

Council of Europe (2020a). Origins and History, https://www.coe.int/en/web/congress//origins-and-hist ory\#\{\%222.988.6548\%22:[0],\%222.988.6575\%22:[0],\%222.988.6634\%22:[0],\%225.039.9899\%22: [0]\} (Erişim tarihi: 16.05.2020). 
Council of Europe (2020b). Political Groups, http://www.congress-political-groups.eu/en/ (Erişim tarihi: 09.05.2020).

Council of Europe (2020c). Nurhayat Altun, Member of the Congress, https://www.coe.int/en/web/congress/ bureau (Erişim tarihi: 15.05.2020).

Council of Europe (2020d). News 2020-Turkey: Monitoring Committee Examines the Application of the European Charter of Local Self-Government, https://www.coe.int/en/web/congress/-/turkeymonitoring-committee-examines-the-application-of-the-european-charter-of-local-selfgovernment (Erişim tarihi: 29.05.2020).

Dursun, H. (2007). Belediye Dizgesine Getirilen Yeniliklere Genel Bir Bakış. TBB Dergisi, Sayı 70, ss.359426.

Erbay, Y. ve Keleş, R. (2013). Bölge Yönetimlerinin Özerkliği ve Avrupa Konseyi. Çağdaş Yerel Yönetimler, Cilt 22, Sayı 1, ss.23-39.

Eryiğit, B. H. (2015). Belediyelerin Vesayet Denetimine Farklı Bir Bakış. Kastamonu Üniversitesi İktisadi ve İdari Bilimler Fakültesi Dergisi, Say1 8, ss.226-235.

Gözler, K. (2019). Türk Belediye Sistemi Üzerinde Fransız Etkisi: 3 Nisan 1930 Tarihli Belediye Kanunu Fransa'dan mı İktibas Edilmiştir? Çağdaş Yerel Yönetimler Dergisi, Cilt 28, Sayı 1-2, s.1-24.

haberturk.com (2010). Aytaç Durak görevden alındı. 28 Mart 2010, https://www.haberturk.com/yasam/ haber/503772-aytac-durak-gorevden-alindi (Erișim tarihi: 03.06.2020)

Haktankaçmaz, M. İ. (2011). Türkiye’nin Reform Deneyimi Işı̆̆ında Son Dönem Kamu Yönetimi Reformlarının Değerlendirilmesi. Ahmet Kesik ve Hasan Canpolat (der.), Küreselleşme ve Kamu Yönetiminde Dönüşüm içinde (69-93) Ankara: Seçkin Yayıncılık.

Haktankaçmaz, M. İ. (2012). Avrupa Konseyi Yerel ve Bölgesel Yönetimler Kongresi Nedir, Ne Değildir?. Iller ve Belediyeler Dergisi, Say1 768, ss.39-52.

Işıkçı, Y. M. (2018). Avrupa Birliği’nde Bölge Yönetimleri: İki Örnek ve Türkiye İçin Bir Değerlendirme. Adıyaman Üniversitesi Sosyal Bilimler Enstitüsü Dergisi, Sayı 28, ss.202-236. DOİ:10.14520/ adyusbd.311094

İçişleri Bakanlığı (2017). Mahalli İdareler Genel Müdürlüğü, 2017 Yll Mahalli İdareler Genel Faaliyet Raporu. http://webdosya.csb.gov.tr/db/yerelyonetimler/icerikler//2017_m-_gnl_faal_rpr201.809.04082437.pdf (Erişim tarihi: 04.06.2020).

İçişleri Bakanlığı (2020). İçişleri Bakanlığından 'İmamoğlu’na soruşturma' haberine ilişkin açılama. Anadolu Ajansl, 18 Mayis 2020, https://www.aa.com.tr/tr/turkiye/icisleri-bakanligindan-imamoglunasorusturma-haberine-iliskin-aciklama/1845703 (Erişim tarihi: 26.05.2020).

Keleş, R. (1995). Yerel Yönetimler Özerklik Şartı Karşısında Avrupa ve Türkiye. Çağdaş Yerel Yönetimler, Cilt 4, Sayı 6, 1995, ss.3-19.

Keleş, R. (1996). Avrupa’da Yerel Yönetimler Üzerinde Denetim ve Türkiye. Uluslararası Konferans, Ankara, TBD-KAV Yayınıdan aktaran Abdullah Çelik (2005). Belediye Başkanlarının Geçici Olarak Görevden Uzaklaştırılması Üzerine Bir Çalışma. Elektronik Sosyal Bilimler Dergisi, Cilt 4, Sayı 14, ss.145-159.

Keleş, R. (2010). Avrupa’ya Uyum Sağlama Sürecinde Türkiye’de Yerel Yönetimler, Nihat Falay vd. (der.), Türkiye'de Yerel Yönetimlerin Sorunları ve Geleceği, İkinci Baskı içinde (20-29), Ankara: Seçkin Yayıncilik.

Keleş, R. (2011). Ulusaltı Birimlerin Özerkliği Üzerine. Ahmet Kesik ve Hasan Canpolat (der.), Küreselleşme ve Kamu Yönetiminde Dönüşüm, Birinci Baskı içinde (1-16), Ankara: Seçkin Yayıncılık. 
Keleş, R. ve Erbay, E. (1999). Avrupa Konseyi’nin Bölge Olgusuna Bakışı. Çağdaş Yerel Yönetimler, Cilt 8, Say1 4, ss.3-29.

Keleş, R. ve Özgül, C. G. (2017). Belediye Organlarına “Kayyım” Atamaları Üzerine Bir Değerlendirme. Ankara Üniversitesi SBF Dergisi, Cilt 72, Say 2, ss.299-313. DOİ:10.1501/SBFder_000.000.2446

Köşger, Y. S. ve Haktankaçmaz, M. İ. (2011). Avrupa Konseyi Tarafından Yerel Yönetimler Alanında Hazırlanan Anlaşmalar. İdarecinin Sesi Dergisi, Sayı 146, ss.50-53.

On Dört İlde Büyükşehir Belediyesi ve Yirmi Yedi İlçe Kurulması ile Bazı Kanun ve Kanun Hükmünde Kararnamelerde Değişiklik Yapılmasına Dair Kanun (2012). https://www.mevzuat.gov.tr/ MevzuatMetin/1.5.6360.pdf (Erişim tarihi: 03.06.2020).

Öncü, A. S. ve Cevizliler, E. (2013). Avrupa Bütünleşmesi İçin Önemli Bir Adım: “Avrupa Konseyi” ve Türkiye’nin Konseye Üyeliği Meselesi. Gazi-Akademik Bakış, Cilt 7, Sayı 13, ss.15-44.

Sertesen, S. (2011). Yerel Yönetim Reformu Kapsamında Yerel Yönetimlerin İdari Özerkliği Nasıl Tartışılmalı?. TEPAV Politika Notu, http://www.tepav.org.tr/upload/files/131.944.0032-9.Yerel_ Yonetim_Reformu_Kapsaminda_Yerel_Yonetimlerin_Idari_Ozerkligi_Nasil_Tartisilmali.pdf (Erişim tarihi: 01.06.2020).

Sobac1, M. Z. (2015). Türkiye’nin Avrupa Yerel Yönetimler Özerklik Şartina Uyumu: Özerklik Miti. SETA, Sayı 120, http://file.setav.org/Files/Pdf/201.504.03121644_turkiyenin-avrupa-yerel-yonetimlerozerklik-sarti\%E2\%80\%99na-uyumu-ozerklik-miti-pdf.pdf (Erişim tarihi: 12.01.2019).

TBMM (2020a). Belediye Kanunu Tasarısı. https://www2.tbmm.gov.tr/d22/1/1-1038.pdf (Erişim tarihi: 15.05.2020).

TBMM (2020b). İl Özel İdaresi Hakkında 24.6.2004 tarihli ve 5197 sayll Kanun ve Anayasanın 89 ve 104 üncü Maddeleri Gereğince Cumhurbaşkanınca Bir Daha Görüşülmek Üzere Geri Gönderme Tezkeresi. https://www2.tbmm.gov.tr/d22/1/1-0856.pdf (Erişim tarihi: 15.05.2020).

Toksöz, F. ve Gezici, F. (2014). Türkiye’de Bölgesel Yönetim-Bir Model Önerisi. İstanbul: TESEV Yayınları, https://www.tesev.org.tr/wp-content/uploads/rapor_Turkiyede_Bolgesel_Yonetim_Bir_Model_ Onerisi.pdf (Erişim tarihi: 06.05.2020).

Yeter, E. (1996). Avrupa Yerel Yönetimler Özerklik Şartı Karşısında Türkiye: Anayasa ve İlgili Yasalarda Durum. Çă̆daş Yerel Yönetimler, Cilt 5, Sayı 1, ss.3-13.

Yıldırım, B. (2017). Görevden Uzaklaştırılan 106 Belediye Başkanı Var. memurlar.net, 11 Aralık 2017, https://www.memurlar.net/haber/714181/gorevden-uzaklastirilan-106-belediye-baskani-var.html (Erişim tarihi: 03.06.2020).

Yılmaz, Z. (2018). Yerel Özerkliğe İlişkin Avrupa Şartı Işı̆̆ında Türkiye’de Yerel Özerklik Hakkı (Doktora tezi, Galatasaray Üniversitesi), https://tez.yok.gov.tr/UlusalTezMerkezi/tezSorguSonucYeni.jsp (Erişim tarihi: 19.10.2020).

Yontar İ. G. ve Özer, Y.E. (2018). Yerel Demokrasinin Kalite Göstergesi Olarak İdari ve Mali Özerklik. Hukuk ve İktisat Araştırmaları Dergisi, Cilt 10, Sayı 2, ss.99-110.

Zorluoğlu, M. (2011). Local Authorities in Turkey. Local Administration Reform in Turkey (LAR II) Project kapsamında İçişleri Bakanlığı-Mahalli İdareler Genel Müdürlüğü Yayını. 


\title{
Local Democracy in Turkey in the Decisions of the Congress of Local and Regional Authorities of the Council of Europe: Challenges and Suggestions
}

\author{
Mehmet İlker HAKTANKAÇMAZ **
}

One of the aims of the Council of Europe (the Council) Turkey is the founding member of it, is to strengthening local and regional self-government as it is perceived a main component of peace and stability in Europe. The Congress of Local and Regional Authorities (the Congress) as one of the advisory bodies of the Council, is mainly responsible for strengthening of local and regional self-government in member states and undertakes various works and prepares reference texts to realize this aim. The Congress is made up of two chambers: the Chamber of Local Authorities and the Chamber of Regions. It has 324 full and 324 substitute members, all appointed by member states according to specific rules to this issue. The European Charter of Local Self-Government (the Charter) is the most well-known and binding text among these which aims at guarantying self-government at local level whereas the Reference Framework for Regional Democracy is a non-binding text prepared by the Congress to guide the governments to improve democracy at regional level. In this frame, the Congress conducts regular general country-by-country monitoring exercises to evaluate the application of the Charter or can carry out urgent fact-finding missions to look into cases of concern, which makes the Congress unique among the similar institutions working in this field. For this purpose, following the official visits to the member state to be monitored, a report is prepared including findings of the monitoring delegation and finally a recommendation is made on the basis of the report, which draws general appearance of local and regional governmental system and gives necessary amendments to be made for improving the system or eliminating the issues which constitutes a threat for effective functioning of local and regional self-government. Numerous legislative reforms have been set in motion by member states on the basis of the findings of these monitoring activities (Council of Europe, 2015, s.6-8; Haktankaçmaz, 2012, s.39-44).

Turkey, as a member of the Council and a signatory of the Charter, has been subjected to these monitoring activities by the Congress. To date, many local governmental reforms have been realized in Turkey, one of the aim of them have been increasing harmonization of the Turkish

** Turkish Ministry of Interior, Ankara, E-mail: ilker63@gmail.com 
local government system with the Charter. The monitoring reports and recommendations of the Congress on Turkish local government system have led Turkish local government reform efforts. In this respect, the aim of this Paper, by analysing the monitoring reports, the recommendations and other decisions made about Turkey by Congress, is to; reveal the perception of the Congress about local democracy in Turkey, determine problematic areas which hinder effective functioning of local self-government in Turkey and make suggestions to increase effectiveness of the Congress in leading Turkey's efforts for improving democracy at local level, comparatively with that of the ones on other member states. This is specifically important in such a period when the practice of replacement of mayors who were claimed to be affiliated with terrorist activities with "caretaker (kayyum)" has been intensified and this refreshed the argument about the content of local selfgovernment in Turkey.

Up to date, seven monitoring exercises, three of them were in the form of fact-finding mission, were carried out about Turkey (Congress, 1997a; Congress, 2005a; Congress, 2007; Congress, 2011a; Congress, 2014a; Congress, 2017a), with this figure she is the second most often monitored country among all member states. When the documents prepared after these monitoring exercises were analysed, besides many others, the core issue, since the first monitoring in 1997, has been; the central supervision over local governments and, in this context, suspension of elected representatives of local governments mainly in east and southeast of Turkey by central government due to the article 127 of the Constitution. The Congress has always been decisive against central government interference to the issues which are according to the Charter considered in the sphere of the local governments in all member states. Removal of local elected representatives from office on the basis of administrative decision is the most extreme practice of central government interference. Since Turkey became the party of the Charter, many waves of reform on local government system have been exercised and various legislative amendments have been made. The most comprehensive and recent reform wave was the one intensified in 2004-2005 with the AKP Government. This recent reform wave specifically aimed at increasing compatibility of local government system with international norms, especially with the Charter (TBMM, 2020a; TBMM, 2020b). Though improvements on many issues criticised in the Congress recommendations were made, prohibitions for local assemblies on taking political decisions and usage of languages other than Turkish in the provision of local services which have been the other most repetitive issues of the recommendations besides the authority of central government on the suspension of office remained untouched. Since these untouched issues were seen as the essence of the Congress mission which can be formulated as "playing a role in the solution of the terror problem in the Southeast of Turkey", starting from the 2010, the relations between Congress and Turkey began to deteriorate.

In this context, this Paper argues that; local governments in Turkey are administratively decentralized institutions not independent or politically decentralized units (Erbay ve Keleş, 2013, s.26; Keleş, 2011, s.10). But, since the concept of self-government is argued as if it means political autonomy in Turkey and the "democratic self-government" rhetoric of the pro-Kurdish "Peoples' Democratic Party" which contains elements not related to the Charter, undermines 
the legitimacy of the Charter and the Congress in the eye of Turkish people (Sobac1, 2015, s.28; Yontar ve Özer, 2018, s.99). Furthermore, devotion of the Congress to the issue of removal of local elected representatives in the eastern and south eastern parts of Turkey causes underestimation of the progress achieved in Turkish local democracy and ignorance of other issues which hinders effective functioning of local democracy in Turkey by the Congress. 